\title{
Application of Microextraction-Based Techniques for Screening-Controlled Drugs in Forensic Context-A Review
}

\author{
Samir M. Ahmad ${ }^{1,2,3, * \mathbb{D}}$, Oriana C. Gonçalves ${ }^{1}$, Mariana N. Oliveira ${ }^{1}\left(\mathbb{D}\right.$, Nuno R. Neng $^{1,4, *}$ \\ and José M. F. Nogueira $1,4, *$ (C) \\ 1 Centro de Química Estrutural, Faculdade de Ciências, Universidade de Lisboa, 1749-016 Lisboa, Portugal; \\ ocgp98@gmail.com (O.C.G.); mariananetoliveira@hotmail.com (M.N.O.) \\ 2 Molecular Pathology and Forensic Biochemistry Laboratory, CiiEM, Campus Universitário-Quinta da \\ Granja, Monte da Caparica, 2829-511 Caparica, Portugal \\ 3 Forensic and Psychological Sciences Laboratory Egas Moniz, Campus Universitário-Quinta da Granja, \\ Monte da Caparica, 2829-511 Caparica, Portugal \\ 4 Departamento de Química e Bioquímica, Faculdade de Ciências, Universidade de Lisboa, \\ 1749-016 Lisboa, Portugal \\ * Correspondence: samir.marcos.ahmad@gmail.com (S.M.A.); ndneng@fc.ul.pt (N.R.N.); \\ nogueira@fc.ul.pt (J.M.F.N.)
}

check for

updates

Citation: Ahmad, S.M.; Gonçalves, O.C.; Oliveira, M.N.; Neng, N.R.; Nogueira, J.M.F. Application of Microextraction-Based Techniques for Screening-Controlled Drugs in Forensic Context-A Review. Molecules 2021, 26, 2168. https:// doi.org/10.3390/molecules26082168

Academic Editors: Constantinos

K. Zacharis and Paraskevas

D. Tzanavaras

Received: 23 March 2021

Accepted: 6 April 2021

Published: 9 April 2021

Publisher's Note: MDPI stays neutral with regard to jurisdictional claims in published maps and institutional affiliations.

Copyright: (c) 2021 by the authors. Licensee MDPI, Basel, Switzerland. This article is an open access article distributed under the terms and conditions of the Creative Commons Attribution (CC BY) license (https:// creativecommons.org/licenses/by/ $4.0 /)$.

\begin{abstract}
The analysis of controlled drugs in forensic matrices, i.e., urine, blood, plasma, saliva, and hair, is one of the current hot topics in the clinical and toxicological context. The use of microextractionbased approaches has gained considerable notoriety, mainly due to the great simplicity, cost-benefit, and environmental sustainability. For this reason, the application of these innovative techniques has become more relevant than ever in programs for monitoring priority substances such as the main illicit drugs, e.g., opioids, stimulants, cannabinoids, hallucinogens, dissociative drugs, and related compounds. The present contribution aims to make a comprehensive review on the stateof-the art advantages and future trends on the application of microextraction-based techniques for screening-controlled drugs in the forensic context.
\end{abstract}

Keywords: microextraction-based techniques; screening methods; controlled drugs; opioids; cannabis; amphetamines; hallucinogens; dissociative drugs; new psychoactive substances; forensic matrices

\section{Introduction}

Abuse and drug addiction, as well as their consequences, are one of the major issues in modern societies. The European Monitoring Center for Drugs and Drug Addiction (EMCDDA) classifies drugs as all substances that people take to achieve a change of mental, physical, or emotional state (i.e., psychoactive substances). This definition also includes tobacco, alcohol, medicinal drugs, and volatile substances ("inhalants"). On the other hand, controlled drugs are only those that are listed in the United Nations Single Convention on Narcotic Drugs (New York, 1961; amended 1972), the Convention on Psychotropic Substances (Vienna, 1971), and the Convention against Illicit Traffic in Narcotic Drugs and Psychotropic Substances (Vienna, 1988). These listings, which include more than 250 compounds and precursors, were created to facilitate their control and to limit their use. These compounds include, but are not limited to, cannabis, cocaine, heroin, amphetamines, LSD, ketamine, etc. [1-4]. Over one million seizures of illicit drugs are reported annually in Europe, where cannabis is the most commonly seized drug, accounting for over $70 \%$ of cases. Cocaine ranks second overall (9\%), followed by amphetamines $(5 \%)$, heroin $(5 \%)$ and ecstasy (2\%). It is estimated that about 7500 overdose deaths, involving at least one illicit or controlled drug, occurred in 2015 in the European Union (EU) [2].

For these reasons, the analysis of controlled drugs in forensic matrices, such as urine, blood, plasma, saliva, and even hair, is of paramount importance [5-7]; this includes the initial diagnosis of drug addiction, mandatory screening in some treatment programs 
and in the workplace, doping control, screening as a method of tracking drug effects over time, identification of the substance in case of an overdose, and determination of treatment compliance.

Drug analysis in forensic fluids usually involves four main steps, i.e., enrichment of the target substances from the biological matrices, separation from potential interferences, detection, and data handling. Nevertheless, analyses of biological samples are always challenging due to the very high complexity of these matrices. The presence of endogenous interferences, such as proteins in plasma, serum, and breast milk, as well as inorganic salts in urine, demands for sample treatment prior to instrumental analysis. Additionally, the target compounds are usually present in very low concentrations and, for this reason, sample preparation becomes crucial [8]. As a general rule, most sample preparation stages include an extraction step aiming to transfer the target analytes to a phase more compatible with the instrumental systems, concentrate the solutes if we are dealing with trace analysis, and elimination of undesirable interferences. Modern approaches to sample enrichment run towards the great simplification, miniaturization, easy manipulation of the analytical devices, high-throughput performance, automation, online coupling with instrumental systems, low sample-volume requirements, and the strong reduction or absence of toxic organic solvents in agreement with the green analytical chemistry principles [9-12].

In this regard, liquid- or sorbent-phase microextraction techniques have become prominent both in passive and active modes. The former includes methodologies such as liquidphase microextraction (LPME), single-drop microextraction (SDME), hollow-fiber microextraction (HF-LPME), solvent bar microextraction (SBME), electromembrane microextraction (EME), parallel artificial liquid membrane extraction (PALME), and dispersive liquid-liquid microextraction (DLLME). On the other hand, the latter includes analytical technologies such as solid-phase microextraction (SPME), stir-bar sorptive extraction (SBSE), bar adsorptive microextraction $(\mathrm{BA} \mu \mathrm{E})$, thin film microextraction (TFME), solid-phase extraction (SPE) and micro-solid-phase extraction ( $\mu \mathrm{SPE})$, magnetic-solid-phase extraction (mSPE), molecularly imprinted solid-phase extraction (MISPE), immunoaffinity solid-phase extraction (IASPE), microextraction by packed sorbent (MEPS), and disposable pipette extraction (DPX). For more details on sample preparation for drug analysis, it is recommended to consult several reference books [13-17] and research review articles [5-12,18-30]. These miniaturized analytical approaches have been proposed for more than two decades to monitor controlled drugs in biological matrices, such as opioids and related compounds, cocaine and metabolites, amphetamine-type substances (ATS), cannabinoids, hallucinogens, dissociative drugs, and new psychoactive substances (NPS). However, limited manuscripts cover the broad range of applications of miniaturized techniques for sample preparation in the forensic context. Most review papers are dedicated to specific technique(s), the sorbent/liquid phase, a particular class of controlled drugs, or are in a target sample type $[8,10,11,18]$.The present contribution focuses on an overview regarding the application of all microextraction-based techniques for screening-controlled drugs in the forensic context, including the important analytical characteristics and parameters of several applications. It also discusses the advantages and limitations of miniaturized sample preparation techniques in this context. We believe that the present contribution can facilitate researchers in choosing a particular analytical approach for their application goal.

\section{Screening-Controlled Drugs by Microextraction-Based Techniques \\ 2.1. Opioids and Related Substances}

The classes of drugs known as opiates or opioids include a wide and diverse range of natural and synthetic chemical compounds derived from opium. These drugs have been used for centuries for the purpose of reducing pain; however, in some cases their effects may lead to overdose [31-38]. In England and Wales alone, heroin or morphine was connected to 1200 deaths registered in 2015 [2]. When administrated, most opioids undergo extensive varying degrees of phase 1 and 2 metabolism. Phase 1 metabolism usually precedes phase 2 metabolism, but this is not always the case. Phase 1 metabolism typically subjects 
the drug to oxidation or hydrolysis, whereas phase 2 metabolism conjugates the drug to hydrophilic substances, such as glucuronic acid, sulfate, glycine, or glutathione. The process of metabolism ends when the molecules are sufficiently hydrophilic to be excreted from the body. For more details regarding opioid metabolism it is advisable to consult the work published by Smith [39]. This information is relevant, especially considering that some precautions may be needed when trying to analyze these compounds. Depending on the target compounds and matrices, the hydrolysis of the glucurinated compounds, as well as protein precipitation, may be needed to increase the signal of the target compounds. For this reason, the determination of these compounds in biological matrices requires the development of reliable analytical methods in clinical, forensics, and research contexts.

Several applications have been developed for the analysis of opioids and related substances in forensic matrices using miniaturized sample preparation approaches. Most were based on headspace (HS) or direct immersion SPME and DLLME. Nevertheless, alternative techniques have been also proposed, including EME, HP-LPME, miniaturized SPE, MEPS, and SDME, among others. For example, Vlčková et al. [40] used a fast MEPS coupled directly to the mass spectrometry (MS) method for the determination of methadone in human urine. This approach achieved convenient detection limits $(1.5 \mu \mathrm{g} / \mathrm{L})$ and remarkable recoveries ( 100\%) using only $0.1 \mathrm{~mL}$ of sample. Another relevant work was published by Gonçalves et al. [41], using a very cost-effective technique (BA $\mu \mathrm{E}$ coated with activated carbons (ACs)) for the enrichment of morphine and codeine from human urine matrices. This sample preparation technique was combined with high-performance liquid chromatography-diode array detection (HPLC-DAD), which allowed the researchers to attain suitable detection limits $(0.06-0.90 \mu \mathrm{g} / \mathrm{L})$ and inter-day repeatability $(\leq 8.0 \%)$. Ranjbari et al. [42] reported a work which combines DLLME with HPLC-UV/vis detection for the analysis of methadone in several human biological matrices, using only $0.5 \mathrm{~mL}$ of plasma and urine and $0.1 \mathrm{~mL}$ of saliva and sweat. This methodology presented very good inter-day repeatability $(<6.4 \%)$ and accuracy levels $(\sim 100 \%)$. Habibi-Khorasani et al. [43] developed a molecularly imprinted polymer for SPME fibers for the selective enrichment of tramadol from brain tissues. The data achieved was very good, as well as the extraction yields (76.2-91.2\%) and inter-day repeatability $(\leq 8.2 \%)$, using just $2 \mathrm{~g}$ of sample. Table 1 summarizes with more detail the miniaturized applications discussed herein for the enrichment of opioids and related substances in forensic matrices, with emphasis on the key characteristics on the developed methodologies. Table S1 (Supplementary Materials) contains information regarding other techniques for the determination of these classes of compounds in the forensic context [44-105]. 
Table 1. Microextraction-based approaches for the analysis of opioids and related substances in the forensic matrix.

\begin{tabular}{|c|c|c|c|c|c|c|c|c|c|c|}
\hline Drugs & Matrix & $\begin{array}{l}\text { Sample } \\
\text { Amount }\end{array}$ & $\begin{array}{c}\text { Sample } \\
\text { Pretreatment }\end{array}$ & $\begin{array}{l}\text { Microextraction } \\
\text { Technique }\end{array}$ & $\begin{array}{c}\text { Optimized Experimental } \\
\text { Conditions }\end{array}$ & $\begin{array}{l}\text { Instrumental } \\
\text { System }\end{array}$ & $\begin{array}{l}\mathrm{LOD} \\
(\mu \mathrm{g} / \mathrm{L})\end{array}$ & $\begin{array}{c}\text { Absolute } \\
\text { Recovery (\%) }\end{array}$ & Precision (\%) & Ref. \\
\hline MTD & Urine & $0.1 \mathrm{~mL}$ & - & MEPS & $\begin{array}{ll}\text { - } & \text { Sorbent: } \mathrm{C} 8 \\
\text { - } & \text { Activation: } 100 \mu \mathrm{L} \mathrm{MeOH} \times 3 \\
\text { - } & \text { Conditioning: } 100 \mu \mathrm{L} \mathrm{H} \mathrm{H}_{2} \mathrm{O} \times 3 \\
\text { - } & \text { Samples aspirated and discarded } \times 5 \\
\text { - } & \text { Washing: } 100 \mu \mathrm{L} \mathrm{H}_{2} \mathrm{O} \times 2+100 \mu \mathrm{L} \text { of } 5 \\
& \% \text { MeOH } \times 1 \\
\text { - } & \text { Elution: } 50 \mu \mathrm{L} \text { of } 0.1 \% \mathrm{COOH} \text { in } \mathrm{MeOH}\end{array}$ & MS/MS & 1.5 & 91.7-106.7 & $\leq 11.1$ & [40] \\
\hline TMD & $\begin{array}{l}\text { Rabbit brain } \\
\text { tissue }\end{array}$ & $2 \mathrm{~g}$ & $\begin{array}{ll}\text { - } & \begin{array}{l}\text { Solid-liquid } \\
\text { extraction }\end{array} \\
\text { - } & \text { Centrifugation } \\
\text { - } & \text { Evaporation } \\
\text { - } & \text { Dilution }\end{array}$ & DI-SPME & $\begin{array}{l}\text { - Washing: } 1 \mathrm{~mL} \text { acetone:ACN }(3: 1, v / v) \\
\text { Eluting step: } 0.2 \mathrm{~mL} \mathrm{HCl}(1 \\
\text { mol/L):MeOH }(1: 1, v / v)\end{array}$ & HPLC-UV & 1 & $76.2-91.2$ & $\leq 8.2$ & [43] \\
\hline CODMOR & Urine & $2 \mathrm{~mL}$ & $\begin{array}{ll}- & \text { Filtration } \\
- & \text { Sonication } \\
- & \text { Dilution }\end{array}$ & $\mathrm{BA} \mu \mathrm{E}$ & $\begin{array}{ll}\text { - } & \text { Coating: } \mathrm{ACs} \\
\text { - } & \text { Extraction: } 2.5 \mathrm{~h}, 1000 \mathrm{rpm}(\mathrm{pH} 7) \\
\text { - } & \text { EvapooH } \mathrm{MeO} / \mathrm{ACN}(1: 1,1.5 \mathrm{~mL}), 30 \mathrm{~min} \\
& \text { redissolution to dryness and }\end{array}$ & HPLC-DAD & $\begin{array}{l}0.06- \\
0.90\end{array}$ & $38.4-41.3$ & $\leq 8.0$ & [41] \\
\hline
\end{tabular}

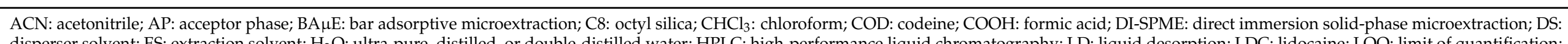

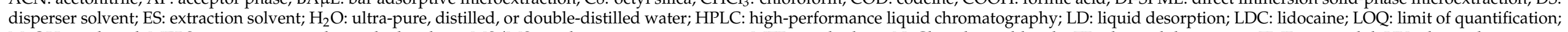
$\mathrm{MeOH}$ : methanol; MEPS: microextraction by packed sorbent; MS/MS: tandem mass spectrometry; MTD: methadone; NaCl: sodium chloride; TD: thermal desorption; TMD: tramadol; UV: ultraviolet. 


\subsection{Stimulants and Related Substances}

One of the most common controlled stimulant drugs is cocaine. It is a naturally occurring substance found in leaves of Erythroxylon coca (containing between $0.6 \%$ and $1.8 \%$ alkaloidal cocaine), a plant endogenous in South America, Mexico, Indonesia, and the West Indies $[31,32,35,106]$. By the turn of the 20th century, cocaine's addictive properties became well-known, and nowadays, it is classified as a Schedule II drug in the United States of America (USA), owing to its high potential for abuse [107,108]. In 2016, an estimated 18.2 million people were described as cocaine users, of which there were more than 10,000 related deaths in the USA [109] and 100 in Turkey [110].

Several applications have been developed for the analysis of cocaine and related substances in forensic matrices using miniaturized sample preparation approaches. Most were based on $\mu$ SPE, HS, or direct immersion SPME and HP-LPME approaches. Nevertheless, other techniques were also proposed, including EME, DLLME, and DPX. A fairly recent work developed by Rosado et al. for the rapid analysis (15 $\mathrm{min})$ of cocaine and metabolites in urine matrices using MEPS and microwave derivatization followed by gas chromatography coupled to mass spectrometry (GC-MS) [111]. The methodology was fully validated and allowed for the quantification of the target compounds in real matrices. Another work employed HP-LPME for the enrichment of cocaine and metabolites from breast milk followed by derivatization and GC-MS analysis [112]. This methodology employed only $30 \mathrm{~min}$ of equilibrium time, allowing researchers to extract up to $67 \%$ of the target compounds. Sánches-Gonzáles et al. [113] developed a magnetic imprinted polymer using $\mu \mathrm{SPE}$ to selectively and quickly $(\sim 4 \mathrm{~min})$ retain cocaine and its main metabolites from plasma samples. The optimized methodology was combined with liquid chromatography tandem mass spectrometry (LC-MS/MS) analysis, resulting in very low detection limits $(0.013-0.36 \mathrm{pg} / \mathrm{mL})$. Table 2 resumes with detail these miniaturized applications for the enrichment of cocaine and related substances in forensic matrices, with emphasis on the key characteristics on the developed methodologies. Table S2 (Supplementary Material) contains information regarding other techniques for the determination of these classes of compounds in the forensic context $[52,84,99,100,104,114-133]$. 
Table 2. Microextraction-based approaches for the analysis of cocaine and related substances in the forensic matrix.

\begin{tabular}{|c|c|c|c|c|c|c|c|c|c|c|}
\hline Drugs & Matrix & $\begin{array}{l}\text { Sample } \\
\text { Amount }\end{array}$ & $\begin{array}{c}\text { Sample } \\
\text { Pretreatment }\end{array}$ & $\begin{array}{l}\text { Microextraction } \\
\text { Technique }\end{array}$ & $\begin{array}{c}\text { Optimized experimental } \\
\text { Conditions }\end{array}$ & $\begin{array}{c}\text { Instrumental } \\
\text { System }\end{array}$ & $\begin{array}{l}\text { LOD } \\
(\mu \mathrm{g} / \mathrm{L})\end{array}$ & $\begin{array}{c}\text { Absolute } \\
\text { Recovery (\%) }\end{array}$ & Precision (\%) & Ref. \\
\hline $\begin{array}{l}\text { CCE } \\
\text { COC } \\
\text { NC }\end{array}$ & Breast milk & $0.5 \mathrm{~mL}$ & $\begin{array}{ll}- & \mathrm{pH} \text { adjustment } \\
\text { - } & \text { Salt addition }\end{array}$ & HF-LPME & $\begin{array}{ll}\text { - } & \text { Extraction: } 30 \mathrm{~min}(2400 \mathrm{rpm}, \\
& \text { pH 9.0, } 25 \% \mathrm{NaCl}) \\
\text { - } & \text { SLM: } 1 \text {-octanol } \\
\text { - } & \text { AP: } 0.4 \mathrm{~mol} / \mathrm{L} \mathrm{HCl} \\
\text { - } & \text { Evaporation } \\
& \text { Derivatization } \\
\end{array}$ & GC-MS & $5-7$ & $32.0-67.4$ & $\leq 15.9$ & [112] \\
\hline $\begin{array}{c}\text { BE } \\
\text { COC } \\
\text { ECGME }\end{array}$ & Urine & $0.2 \mathrm{~mL}$ & $\begin{array}{ll}- & \text { Centrifugation } \\
- & \text { Dilution } \\
- & \text { pH adjustment }\end{array}$ & MEPS & $\begin{array}{ll}\text { - } & \text { Sorbent: } 80 \% \mathrm{C} 8+20 \% \mathrm{SCX} \\
& \text { Conditioning: } 250 \mu \mathrm{L} \mathrm{MeOH} \times \\
& 1+250 \mu \mathrm{L} 0.1 \% \mathrm{COOH} \times 1 \\
\text { - } & \text { Samples aspirated and } \\
& \text { discarded } \times 6 \\
\text { - } & \text { Washing: } 50 \mu \mathrm{L} 0.1 \% \mathrm{COOH} \times \\
& 4+\text { drying } \\
\text { - } & \begin{array}{l}\text { Elution: } 100 \mu \mathrm{L} \text { of } 1 \% \mathrm{NH}_{4} \mathrm{OH} \\
\text { in MeOH } \times 4\end{array} \\
\text { - } & \begin{array}{l}\text { Evaporation to dryness and } \\
\text { derivatization }\end{array}\end{array}$ & GC-MS & $\begin{array}{c}25 \\
(\mathrm{LLOQ})\end{array}$ & $14.5-83.3$ & $\leq 14.38$ & [111] \\
\hline $\begin{array}{c}\text { BE } \\
\text { CCE } \\
\text { COC } \\
\text { ECGME }\end{array}$ & Plasma & $0.1-1.0 \mathrm{~mL}$ & $\begin{array}{ll}\text { - } & \mathrm{pH} \text { adjustment } \\
\text { - } & \text { Dilution }\end{array}$ & $\mu \mathrm{SPE}$ & $\begin{array}{ll}\text { - } & \text { Sorbent: } \mathrm{MMIP} \\
& \text { Extraction: } 4 \mathrm{~min}\left(20{ }^{\circ} \mathrm{C}, 100\right. \\
\text { - } & \text { Elution: } 2 \mathrm{~mL} \\
& \mathrm{DCM} / \mathrm{m}-\mathrm{IPA} / \mathrm{NH}_{4} \mathrm{OH}(75: 20: 5, \\
& \text { v:v:v), ultrasound irradiation } \\
& (5 \mathrm{~min}) \\
\text { - } & \text { Evaporation to dryness } \\
\text { - } & \text { Redissolved with } 0.04 \mathrm{~mL} \text { of } \\
& 2 \mathrm{mM} \mathrm{C}_{2} \mathrm{H}_{7} \mathrm{NO}_{2} \text { in } \mathrm{MeOH}\end{array}$ & LC-MS/MS & $\begin{array}{c}0.000013- \\
0.00036\end{array}$ & 91-102 & $\leq 10$ & [113] \\
\hline
\end{tabular}

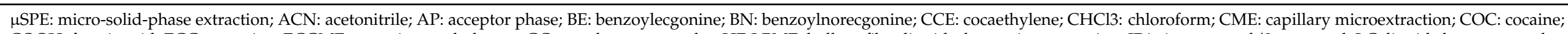

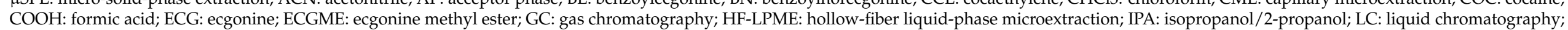

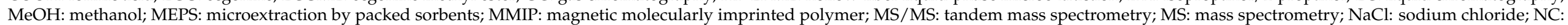
norcocaine; n-C6: n-hexane; NCE: norcocaethylene; PDMS: polydimethylsiloxane; SCX: silica-based cationic exchange polymer; SLM: supported liquid membrane. 
Another important class of stimulant drugs are amphetamine (AMP) and amphetaminetype substances (ATS), which include methamphetamine (MAMP), 3,4-methylenedioxymethamphetamine (MDMA, ecstasy), N-ethyl-3,4-methylenedioxyamphetamine (MDEA), and methylenedioxyamphetamine (MDA). These compounds are derived from ephedra (Ephedra sinica), a native plant from China and Mongolia [134,135]. Stimulants such as cocaine, amphetamines, MDMA, and cathinones are implicated in several overdose deaths in Europe. For instance, stimulant-related deaths in Turkey totaled 206 cases related to amphetamines and 166 cases related to MDMA in 2015 [2].

Several applications have been developed for the analysis of amphetamine and related substances in forensic matrices using miniaturized sample preparation approaches. Most were based on HS or direct immersion SPME, DLLME, and HP-LPME. Nonetheless, other techniques were also proposed, including EME, SDME, DPX, and dSPE, among others. Recently, Song and Yang [136] employed an electric field to accelerate the mass transfer of AMP and MAMP from urine to a single-drop extraction phase, resulting in recovery yields of up to $96 \%$. Taghvimi et al. [137] introduced a metal organic framework-based carbon porous as an efficient dSPE for the enrichment of MAMP from urine samples. Maddadi et al. [138] developed a floating HP-LPME-based methodology for the extraction, preconcentration, and determination of methylphenidate in urine matrices. The results showed good inter-day repeatability levels $(\leq 3.9 \%)$, using only $25 \mathrm{~min}$ of microextraction time. Abbasian et al. [139] developed a new SPME fiber based on multiwalled carbon nanotubes and ionic liquids for the separation and determination of methamphetamine and MDMA in human urine using a sol-gel preparation. The results showed high sensitivity $(0.097-0.390 \mathrm{ng} / \mathrm{mL})$ and suitable inter-day repeatability $(\leq 7.0 \%)$. Table 3 summarizes in detail these miniaturized applications for the enrichment of amphetamine and related substances in forensic matrices, with emphasis on the key characteristics on the developed methodologies. Table S3 (Supplementary Material) contains information regarding other techniques for the determination of these classes of compounds in the forensic context [40,89-98,100,104,105,129-131,140-200]. 
Table 3. Microextraction-based approaches for the analysis of amphetamine and related substances in the forensic matrix.

\begin{tabular}{|c|c|c|c|c|c|c|c|c|c|c|}
\hline Drugs & Matrix & $\begin{array}{l}\text { Sample } \\
\text { Amount }\end{array}$ & Sample Pretreatment & $\begin{array}{l}\text { Microextraction } \\
\text { Technique }\end{array}$ & $\begin{array}{l}\text { Optimized Experimental } \\
\text { Conditions }\end{array}$ & $\begin{array}{l}\text { Instrumental } \\
\text { System }\end{array}$ & $\begin{array}{l}\text { LOD } \\
(\mu \mathrm{g} / \mathrm{L})\end{array}$ & $\begin{array}{c}\text { Absolute } \\
\text { Recovery (\%) }\end{array}$ & $\begin{array}{l}\text { Precision } \\
\quad(\%)\end{array}$ & Ref. \\
\hline \multirow{2}{*}{$\begin{array}{l}\text { AMP } \\
\text { 4-MAMP }\end{array}$} & \multirow[b]{2}{*}{ Urine } & \multirow[b]{2}{*}{$1 \mathrm{~mL}$} & \multirow{2}{*}{$\begin{array}{ll}- & \text { Filtration } \\
- & \text { Dilution } \\
- & \text { pH adjustment } \\
\text { - } & \text { Derivatization }\end{array}$} & EE-SDME & $\begin{array}{ll}\text { - } & \text { Solvent: DCM }(2 \mu \mathrm{L}) \\
\text { - } & \text { Extraction: } 4 \min (-4 \mathrm{~V}, \mathrm{pH} 7)\end{array}$ & \multirow[b]{2}{*}{ GC-FID } & $0.14-0.27$ & $82.7-96.2$ & $\leq 12.8$ & \multirow[b]{2}{*}{ [136] } \\
\hline & & & & HS-SPME & $\begin{array}{ll}\text { - } & \text { Coating: PDMS-DVB } \\
\text { - } & \text { Extraction: } \mathrm{pH} 7,40 \mathrm{~min} \\
& \left(600 \mathrm{rpm}, 60^{\circ} \mathrm{C}\right) \\
\text { - } & \text { TD: } 5 \mathrm{~min}, 250^{\circ} \mathrm{C} \\
\end{array}$ & & $0.05-0.09$ & $90.7-112.5$ & $\leq 8.5$ & \\
\hline MET & Urine & $5 \mathrm{~mL}$ & $\begin{array}{ll}\text { - } & \text { pH adjustment } \\
\text { Centrifugation }\end{array}$ & dSPE & $\begin{array}{ll}- & \text { Sorbent: ZIFs }(40 \mathrm{mg}) \\
- & \text { Extraction: } 5 \mathrm{~min}(2000 \mathrm{rpm}) \\
- & \text { Centrifugation } \\
- & \text { Desorption: } 400 \mu \mathrm{L} \mathrm{MeOH} \\
& \text { (sonication for } 10 \mathrm{~min}) \\
& \text { Centrifugation }\end{array}$ & HPLC-UV & 10 & 99.83 & $\leq 5.1$ & [137] \\
\hline MPH & Urine & $2.5 \mathrm{~mL}$ & $\begin{array}{ll}\text { - } & \text { Dilution } \\
\text { - } & \text { Centrifugation } \\
\text { - } & \text { NH adjustment } \\
& \mathrm{NaCl} \text { addition }\end{array}$ & SBME & $\begin{array}{ll}\text { - } & \text { Extraction: } 25 \mathrm{~min}(650 \mathrm{rpm}, \mathrm{pH} \\
& \left.11.6,25^{\circ} \mathrm{C}, 30 \% \mathrm{NaCl}(w / v)\right) \\
\text { - } & \text { SLM: } 1 \text {-octanol } \\
\text { - } & \text { AP: } \mathrm{pH} 4.0,30 \mu \mathrm{L} \\
\end{array}$ & HPLC-UV & 15 & n.a. & $\leq 3.9$ & [138] \\
\hline $\begin{array}{l}\text { MDMA } \\
\text { MET }\end{array}$ & Urine & $2 \mathrm{~mL}$ & $\begin{array}{l}\text { - } \quad \mathrm{NaCl} \text { addition } \\
\text { - } \quad \mathrm{pH} \text { adjustment }\end{array}$ & HS-SPME & $\begin{array}{ll}\text { - } & \text { Coating: MWCNTs } / \mathrm{ILs} \\
\text { - } & \text { Extraction: } \mathrm{pH} 11,20 \mathrm{~min}, 20 \% \\
& \mathrm{NaCl}(w / v)\left(500 \mathrm{rpm}, 80^{\circ} \mathrm{C}\right) \\
\text { - } & \mathrm{TD}: 4 \mathrm{~min}, 250^{\circ} \mathrm{C}\end{array}$ & GC-FID & $0.097-0.39$ & n.a. & $\leq 7.0$ & [139] \\
\hline
\end{tabular}

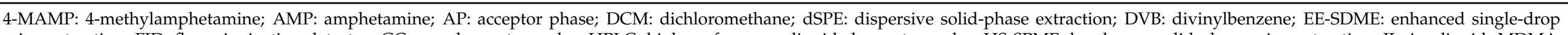

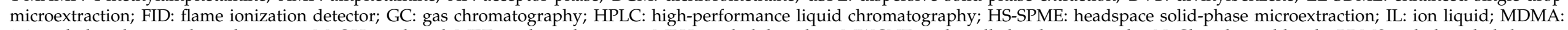

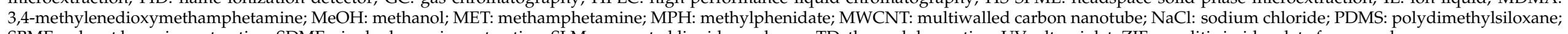
SBME: solvent bar microextraction; SDME: single-drop microextraction; SLM: supported liquid membrane; TD: thermal desorption; UV: ultraviolet; ZIFs: zeolitic imidazolate frameworks. 


\subsection{Cannabinoids and Related Substances}

Cannabis sativa, more commonly known as "marijuana", is a hemp plant that grows freely throughout the world [31]. It is estimated that the global number of users of cannabis is around 182.5 million. The total number of cannabis seizures (including herd and resin) in 2014 was more than 7000 tons [1]. In the EU alone, herbal and resin cannabis accounted for around $69 \%$ of total seizures (568 tons) in 2016 [48].

The first chemical analysis of cannabis apparently was performed in 1821 . Since then, studies have shown cannabis to be a complex plant, in which more than 400 individual chemical compounds have been identified. The most potent cannabinoid is $\Delta-9$ tetrahydrocannabinol (THC) and other relevant ones include, $\Delta$-8-tetrahydro-cannabinol (8-THC), cannabidiol (CBD), and cannabinol (CBN).

Several applications have been developed for the analysis of cannabinoids and related substances in biological matrices using miniaturized sample preparation approaches. Most were based on HS or direct immersion SPME and DPX. Nevertheless, other techniques were also employed, including MEPS, HF-LPME, and $\mu$ SPE, among others. Anderson et al. [201] developed DPX containing a weak anionic exchange polymer to selectively extract 11 cannabinoids and metabolites from human urine samples. This methodology was followed by LC-MS/MS, resulting in suitable extraction efficiencies (up to 81\%) and convenient detection limits (0.5-5.0 ng/mL). Sánchez-González et al. [202] developed a molecularly imprinted polymer (MIP) for $\mu \mathrm{SPE}$ to selectively retain $\mathrm{THC}, \mathrm{THC}-\mathrm{COOH}$, and THC-OH from plasma and urine, followed by LC-MS/MS. To produce the MIP, the authors used $\mathrm{THC}-\mathrm{COOH}$ as a template molecule, whereas ethylene glycol dimethacrylate was used as a functional monomer, divinylbenzene as a cross-linker, and 2,2' -azobisisobutyronitrile as an initiator. The optimized methodology allowed the researchers to attain high recovery yields (up to $94 \%$ ) using only $12 \mathrm{~min}$ of equilibrium time. Using a conventional HS-SPME-based methodology, Silveira et al. [203] were able to selectively extract three cannabinoids from human breast milk. The microextraction step was followed by thermal desorption (TD) and GC-MS analysis, resulting in suitable sensitivity $(10 \mathrm{ng} / \mathrm{mL})$ using only $0.05 \mathrm{~mL}$ of sample. On the other hand, Emídio et al. [204] applied a HF-LPME-based methodology for the enrichment of the same cannabinoids from hair samples using GC-MS as instrumental system. The results indicated good detection limits (0.5-15 pg/mg) using only $10 \mathrm{mg}$ of sample. Table 4 summarizes in detail these miniaturized applications for the enrichment of cannabinoids and related substances in forensic matrices, with emphasis on the key characteristics on the developed methodologies. Table S4 (Supplementary Material) contains information regarding other techniques for the determination of these classes of compounds in the forensic context $[89,100,205-219]$. 
Table 4. Microextraction-based approaches for the analysis of cannabinoids and related substances in the forensic matrix.

\begin{tabular}{|c|c|c|c|c|c|c|c|c|c|c|}
\hline Drugs & Matrix & Sample Amount & Sample Pretreatment & $\begin{array}{l}\text { Microextraction } \\
\text { Technique }\end{array}$ & $\begin{array}{l}\text { Optimized Experimental } \\
\text { Conditions }\end{array}$ & $\begin{array}{l}\text { Instrumental } \\
\text { System }\end{array}$ & $\begin{array}{c}\text { LOD } \\
(\mu \mathrm{g} / \mathrm{L})\end{array}$ & $\begin{array}{c}\text { Absolute } \\
\text { Recovery (\%) }\end{array}$ & Precision (\%) & Ref. \\
\hline $\begin{array}{l}\text { THC } \\
\text { CBN } \\
\text { CBD }\end{array}$ & Breast milk & $0.05 \mathrm{~mL}$ & $\begin{array}{ll}- & \text { Dilution } \\
- & \text { pH adjustment }\end{array}$ & HS-SPME & $\begin{array}{ll}\text { - } & \text { Sorbent: PDMS } \\
\text { Extraction: } 70^{\circ} \mathrm{C}, 40 \mathrm{~min}, \\
\quad 25 \% \mathrm{NaCl} \\
\text { - } \quad \text { TD: } 2500^{\circ} \mathrm{C} \\
\end{array}$ & GC-MS & 10.0 & n.a. & $\leq 13.3$ & [203] \\
\hline $\begin{array}{c}\text { THC } \\
\text { 11-OH-THC } \\
\text { THC-COOH } \\
\text { CBN } \\
\text { CBD } \\
\text { THCAA } \\
\text { CBG } \\
\text { THCV } \\
\text { THC-gluc } \\
\text { THC-COOH-gluc }\end{array}$ & Urine & $0.2 \mathrm{~mL}$ & $\begin{array}{ll}- & \text { Centrifugation } \\
- & \text { Dilution } \\
& \text { Protein } \\
& \text { precipitation } \\
- & \text { pH adjustment }\end{array}$ & DPX & $\begin{array}{ll}\text { - } & \text { Sorbent: WAX } \\
\text { - } & \text { Samples aspirated } \times 4 \\
& \text { Upper layer diluted and } \\
\text { centrifuged }\end{array}$ & LC-MS/MS & $0.5-5.0$ & $42.4-81.5$ & $\leq 14.3$ & [201] \\
\hline $\begin{array}{l}\text { THC } \\
\text { CBN } \\
\text { CBD }\end{array}$ & Hair & $10 \mathrm{mg}$ & $\begin{array}{ll}\text { - } & \text { Washing } \\
\text { - } & \text { Alkaline digestion } \\
\text { Evaporation to } \\
\text { dryness } \\
\text { - } & \text { Dilution } \\
\end{array}$ & HF-LPME & $\begin{array}{ll}\text { - } & \text { Extraction: } 20 \mathrm{~min}(\mathrm{pH} 14, \\
& 6.8 \% \mathrm{NaCl}, 600 \mathrm{rpm}) \\
\text { - } & \text { SLM: butyl acetate } \\
\text { - } & \mathrm{AP}: 20 \mu \mathrm{L} \text { butyl acetate }\end{array}$ & GC-MS & $0.5-15 \mathrm{pg} / \mathrm{mg}$ & $4.4-8.9$ & $\leq 13.7$ & [204] \\
\hline $\begin{array}{c}\text { THC } \\
\text { 11-OH-THC } \\
\text { THC-COOH }\end{array}$ & Plasma and urine & $\begin{array}{l}\text { Urine: } 1 \mathrm{~mL} \\
\text { Plasma: } 0.1 \mathrm{~mL}\end{array}$ & $\begin{array}{ll}\text { - } & \text { Dilution } \\
\text { pH adjustment }\end{array}$ & $\mu \mathrm{SPE}$ & 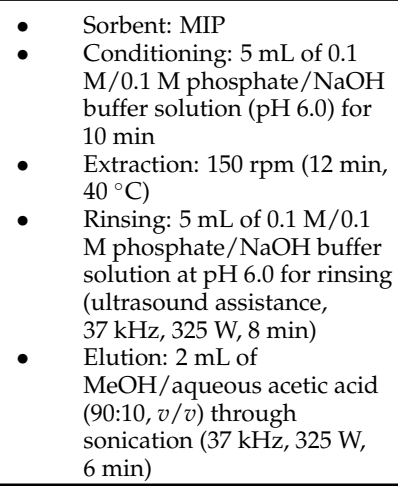 & HPLC-MS/MS & $\begin{array}{c}\text { Urine: } \\
0.14-0.16 \\
\text { Plasma: } \\
0.11-0.15\end{array}$ & $87-94$ & $\begin{aligned} \text { Urine: } & \leq 6 \\
\text { Plasma: } & \leq 11\end{aligned}$ & [202] \\
\hline
\end{tabular}

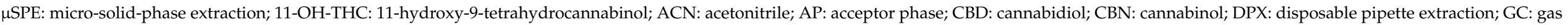

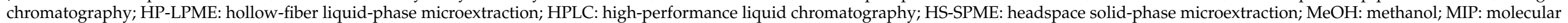

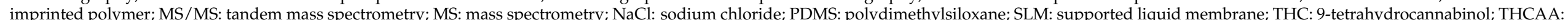

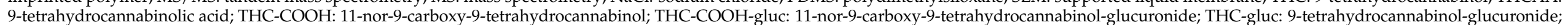
THCV: 9-tetrahydrocannabiverin; THCV-COOH: 11-nor-9-carboxy-9-tetrahydrocannabiverin; WAX: weak anionic exchange. 


\subsection{Hallucinogens, Dissociative Drugs, and Related Substances}

Hallucinogens are substances that promote hallucinations, a unique psychoactive effect, which are profound distortions in a person's perceptions of reality. Hallucinogens can be found in some plants and mushrooms (or their extracts) or can be man-made, and they are commonly divided into two broad categories: classic hallucinogens, including lysergic acid diethylamide (LSD), 4-phosphoryloxy-N,N-dimethyltryptamine (psilocybin), peyote (mescaline), and dimethyltryptamine or ayahuasca (DMT); and dissociative drugs, including ketamine (KET), dextromethorphan, phencyclidine ( $\mathrm{PCP}$ ), and Salvia divinorum. When under the influence of either type of drugs, people often report experiencing rapid, intense emotional swings and seeing images, hearing sounds, and feeling sensations that are unreal [31,32].

To date, there has not been a microextraction-based approach dedicated solely to the determination of classic hallucinogens from forensic matrices, and very few have included these compounds as target analytes in their method development. Nevertheless, recently, Vicenti et al. [100] developed a very comprehensive methodology using DLLME combined with pressurized liquid extraction, and liquid chromatography coupled to high-resolution tandem mass spectrometry (LC-HRMS/MS) for the enrichment of over 60 drugs of abuse in hair, including mescaline. The results showed that the developed method allowed the researchers to attain recovery yields of up to $40 \%$ for mescaline using only $10 \mathrm{mg}$ of sample. Table 5 resumes in detail most of the miniaturized applications for the enrichment of classic hallucinogens and related classes of compounds in the forensic context, with emphasis on the key characteristics of the developed methodologies. 
Table 5. Microextraction-based approaches for the analysis of hallucinogenic drugs and related substances in the forensic matrix.

\begin{tabular}{|c|c|c|c|c|c|c|c|c|c|c|}
\hline Drugs & Matrix & Sample Amount & Sample Pretreatment & $\begin{array}{l}\text { Microextraction } \\
\text { Technique }\end{array}$ & $\begin{array}{c}\text { Optimized Experimental } \\
\text { Conditions }\end{array}$ & $\begin{array}{l}\text { Instrumental } \\
\text { System }\end{array}$ & $\begin{array}{l}\text { LOD } \\
(\mu \mathrm{g} / \mathrm{L})\end{array}$ & $\begin{array}{c}\text { Absolute } \\
\text { Recovery (\%) }\end{array}$ & $\begin{array}{l}\text { Precision } \\
(\%)\end{array}$ & Ref. \\
\hline LSD & Blood & $0.5 \mathrm{~mL}$ & $\begin{array}{ll}\text { - } & \text { Protein precipitation } \\
: & \text { Dentrifugation } \\
: & \text { Salt addition } \\
& \text { pH adjustment }\end{array}$ & DLLME & $\begin{array}{ll}- & \text { DS: } 250 \mu \mathrm{L} \mathrm{MeOH} \\
& \text { ES: } 100 \mu \mathrm{L} \text { chloroform } \\
\bullet & \text { Rapid injection } \\
\bullet & \text { Sonication }(1 \mathrm{~min}) \\
& \text { Centrifugation }(4000 \mathrm{rpm}, 5 \mathrm{~min}) \\
& \begin{array}{l}\text { Infranatant collected, evaporated, and } \\
\text { redissolved }\end{array}\end{array}$ & UPLC-MS/MS & 0.5 & $90-127$ & $\leq 15$ & {$[90]$} \\
\hline LSD & Urine & $4 \mathrm{~mL}$ & $\begin{array}{ll}\text { - } & \text { Dilution } \\
\text { - } & \text { Salt addition } \\
\text { pH adjustment }\end{array}$ & DLLME & $\begin{array}{ll}- & \text { DS: } 1505 \mu \mathrm{L} \mathrm{ACN} \\
: & \text { ES: } 606 \mu \mathrm{L} \mathrm{CH}_{2} \mathrm{Br}_{2} \\
& \text { Extraction: } 30 \% \mathrm{NH}_{3}, \mathrm{pH} \geq 11.5 \\
& \text { Rapid injection } \\
& \text { Centrifugation (9500 rpm,5 min) } \\
& \text { Infranatant collected, evaporated, and } \\
& \text { redissolved }\end{array}$ & CE-UV & $3.9-6.3$ & 80.3 & $\leq 12.0$ & [164] \\
\hline $\begin{array}{l}\text { Psylocibin } \\
\text { Mescaline }\end{array}$ & Oral fluid & $0.090 \mathrm{~mL}$ & $\begin{array}{ll}\text { - } & \text { Centrifugation } \\
\text { - } & \text { pH adjustment } \\
& \text { Dilution }\end{array}$ & $\mu \mathrm{SPE}$ & $\begin{array}{ll}- & \text { Sorbent: } \mathrm{C} 18 \\
\quad & \text { Extraction: } 15 \mathrm{~min}\left(30{ }^{\circ} \mathrm{C}, 200 \mathrm{rpm}\right) \\
\quad & \text { Washing: } 100 \mu \mathrm{L} \mathrm{H}_{2} \mathrm{O} \\
& \text { Elution: } 100 \mu \mathrm{L} \mathrm{MeOH} \text { containing } 10 \\
& \text { mM of } \mathrm{COOH}\end{array}$ & LC-MS/MS & $0.07-0.1$ & $61-64$ & $\leq 9$ & [129] \\
\hline $\begin{array}{l}\text { Mescaline } \\
\text { Psylocibin }\end{array}$ & $\begin{array}{l}\text { Urine } \\
\text { Plasma }\end{array}$ & $\begin{array}{l}\text { Urine: } 0.090 \mathrm{~mL} \\
\text { Plasma: } 0.180 \mathrm{~mL}\end{array}$ & $\begin{array}{ll}\text { - } & \text { Urine samples were } \\
& \text { diluted } \\
\text { - } & \text { Sonication } \\
\text { - } & \text { Centrifugation } \\
\text { - } & \text { DH adjustment } \\
\end{array}$ & $\mu \mathrm{SPE}$ & $\begin{array}{ll}- & \text { Sorbent: } \mathrm{C} 18 \\
\quad & \text { Washing: } 100 \mu \mathrm{L} \mathrm{H} \mathrm{H}_{2} \mathrm{O} \\
& \text { Elution: } 100 \mu \mathrm{L} \mathrm{MeOH} \text { containing } 10 \\
& \text { mM of } \mathrm{COOH}\end{array}$ & LC-MS/MS & $0.3-1.4$ & $57-66$ & $\leq 7$ & [130] \\
\hline $\begin{array}{l}\text { Muscimol } \\
\text { Tryptamine } \\
\text { Tryptophan }\end{array}$ & Urine & $2 \mathrm{~mL}$ & $\begin{array}{ll}- & \text { Dilution } \\
- & \text { Salt addition } \\
- & \text { pH adjustment }\end{array}$ & HF-LPME & $\begin{array}{ll} & \text { SLM: DEHPA in DHE } \\
\text { - } & \text { AP: } \mathrm{HCl} 0.1 \mathrm{~mol} / \mathrm{L} \\
& \text { Extraction: } 60 \mathrm{~min}(800 \mathrm{rpm}, \mathrm{pH} 5, \\
& 0.001 \% \mathrm{NaCl}) \\
\end{array}$ & HPLC-UV & $0.7-17$ & n.a. & $\leq 10.2$ & [220] \\
\hline Mescaline & Hair & $10 \mathrm{mg}$ & $\begin{array}{ll}\text { - } & \text { Washing } \\
\text { - } & \text { Pigestion } \\
\text { - } & \text { Evaporation } \\
\text { - } & \text { Redissolution } \\
\text { - } & \text { Centrifugation } \\
\text { - } & \text { PH } \text { Pilution } \\
& \text { Salt addition } \\
\end{array}$ & PLE-DLLME & $\begin{array}{ll}- & \text { DS: } 500 \mu \mathrm{L} \text { 2-propanol } \\
\text { - } & \text { ES: } 200 \mu \mathrm{L} \text { chloroform } \\
& \text { Extraction: } 24 \% \mathrm{NaCl}, \mathrm{pH} 11.0,10 \% \\
& \text { iso-propanol } \\
- & \text { Sonication }(10 \mathrm{~min}) \\
\quad & \text { Centrifugation }\left(9000 \mathrm{rpm}, 5 \mathrm{~min}, 3^{\circ} \mathrm{C}\right) \\
& \text { Infranatant collected, evaporated, and } \\
& \text { redissolved }\end{array}$ & LC-HRMS/MS & $0.1 \mathrm{pg} / \mathrm{mg}$ & 39 & $\leq 19$ & {$[100]$} \\
\hline
\end{tabular}

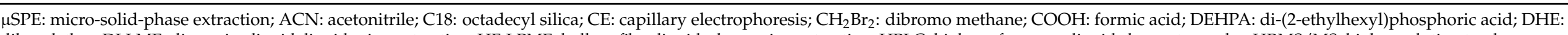

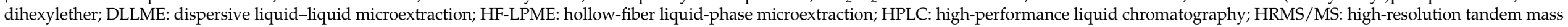

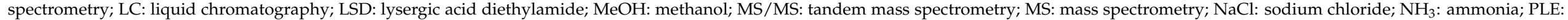
pressurized liquid extraction; UPLC: ultra-performance liquid chromatography; UV: ultraviolet. 
As was mentioned before, another important class to consider is dissociative drugs, which include dextromethorphan, Salvia divinorum, PCP, and KET, in which the latter have been more largely abused than the other dissociative drugs.

PCP was synthesized in 1956 and was tested as an anesthetic because it had pronounced tranquilizing effects. With animals, it produced a general anesthesia that left them conscious but not feeling pain, even during surgery. In clinical trials of PCP with humans, however, some patients experienced hyperexcitability, delirium, and visual disturbances. For this reason, it was largely abandoned for human use [31].

KET was developed in 1962 during a search for a less problematic replacement for PCP. Due to its quick onset and short duration of action with only slight cardiorespiratory depression in comparison with other general anesthetics and the possibility of inhalation to maintain the anesthetic state, KET is a preferred drug for short-term surgical procedures in veterinary and human medicine, especially in children [221]. Several applications have been developed for the analysis of cannabinoids and related substances in forensic matrices using miniaturized sample preparation approaches. Most were based on HS or direct immersion SPME, DLLME, and HF-LPME. Nevertheless, other techniques were also employed, including MEPS, SDME, $\mu \mathrm{SPE}$, and high-throughput bar adsorptive microextraction $(\mathrm{HT}-\mathrm{BA} \mu \mathrm{E})$, among others. One of the first reports using microextraction-based approaches to determine dissociative drugs in forensic matrices was developed by Ishii et al. [222]. These authors used HS-SPME to selectively extract PCP from urine and blood samples followed by thermal desorption and gas chromatography with surface ionization detection (TD/GC-SID) analysis. The results showed that recoveries were up to $48 \%$ with limits of detection between 0.25 and $1.0 \mathrm{ng} / \mathrm{mL}$, depending on the matrix type. Casari and Andrews [195] developed a floating HP-LPME-based methodology for the extraction, preconcentration, and determination of $\mathrm{PCP}$ and other compounds from urine samples. This approach employed only $2 \mu \mathrm{L}$ of chloroform as extraction solvent, resulting in suitable sensitivity with convenient limits of detection $(70 \mathrm{ng} / \mathrm{mL})$. On the other hand, Meng et al. [92] decided to compare HF-LPME and ultrasound-assisted DLLME methodologies combined with GC-MS for the determination of selected drugs of abuse, including KET, in biological samples. The results show similar detection limits, extraction efficiencies and inter-day repeatability levels, although the former employed a smaller amount of organic solvent. More recently, a HT-BA $\mu$ E methodology was developed to monitor KET and its main metabolite (norketamine) in urine matrices, followed by GC-MS. The developed apparatus allows for the extraction and desorption of the target compounds in up to 100 urine samples simultaneously, resulting in an assay time of only $0.45 \mathrm{~min} /$ sample [223]. Table 6 summarizes in detail these miniaturized applications for the enrichment of dissociative drugs and related substances in forensic matrices, with emphasis on the key characteristics on the developed methodologies. Table S5 (Supplementary Material) contains information regarding other techniques for the determination of these classes of compounds in the forensic context [89,90,98,100,105,120,129,130,145,157,164,174,194,196,224-234]. 
Table 6. Microextraction-based approaches for the analysis of dissociative drugs and related substances in the forensic matrix.

\begin{tabular}{|c|c|c|c|c|c|c|c|c|c|c|}
\hline Drugs & Matrix & Sample Amount & Sample Pretreatment & $\begin{array}{l}\text { Microextraction } \\
\text { Technique }\end{array}$ & $\begin{array}{c}\text { Optimized Experimental } \\
\text { Conditions }\end{array}$ & $\begin{array}{c}\text { Instrumental } \\
\text { System }\end{array}$ & $\begin{array}{l}\text { LOD } \\
(\mu \mathrm{g} / \mathrm{L})\end{array}$ & $\begin{array}{c}\text { Absolute } \\
\text { Recovery (\%) }\end{array}$ & Precision (\%) & Ref. \\
\hline PCP & $\begin{array}{c}\text { Urine } \\
\text { Whole blood }\end{array}$ & $1 \mathrm{~mL}$ & $\begin{array}{ll}- & \text { Protein precipitation } \\
- & \text { pH adjustment } \\
& \text { Salt addition } \\
\end{array}$ & HS-SPME & $\begin{array}{ll}\text { - } & \text { Coating: PDMS } \\
\text { - } & \text { Extraction: } 30 \mathrm{~min}, 50 \% \mathrm{~K}_{2} \mathrm{CO}_{3} \\
& (w / v)\left(900 \mathrm{rpm}, 90^{\circ} \mathrm{C}\right) \\
\text { - } & \text { TD: } 2500^{\circ} \mathrm{C} \\
\end{array}$ & GC-SID & $0.25-1.0$ & $9.3-47.8$ & $\leq 27$ & [222] \\
\hline PCP & Urine & $2 \mathrm{~mL}$ & $\begin{array}{ll}\bullet & \text { Filtration } \\
- & \text { pH adjustment }\end{array}$ & SDME & $\begin{array}{ll}\text { - } & \text { Solvent: chloroform }(2 \mu \mathrm{L}) \\
\text { - } & \text { AP: (pH 10.5) } \\
& \text { Extraction: } 8 \text { min, } 0.1 \mathrm{M} \mathrm{NaOH}\end{array}$ & GC-PDHID & 70 & n.a. & $\leq 16.2$ & [195] \\
\hline \multirow[b]{2}{*}{ KET } & \multirow[b]{2}{*}{ Urine Blood } & \multirow[b]{2}{*}{$1 \mathrm{~mL}$} & \multirow[b]{2}{*}{$\begin{array}{ll}\text { - } & \text { Dilution } \\
\text { pH adjustment }\end{array}$} & HF-LPME & $\begin{array}{ll}- & \text { SLM: toluene } \\
\text { - } & \text { AP: toluene }(10 \mu \mathrm{L}) \\
& \text { Extraction: } 10 \mathrm{~min}(500 \mathrm{rpm}, \mathrm{pH} \\
& \left.13.0,30^{\circ} \mathrm{C}\right) \\
\end{array}$ & \multirow[b]{2}{*}{ GC-MS } & 2.5 & $81.3-98.6$ & $\leq 4.5$ & \multirow[b]{2}{*}{ [92] } \\
\hline & & & & DLLME & $\begin{array}{ll}\text { - } & \text { ES and DS: } 100 \mu \mathrm{L} \text { toluene } \\
& \text { Sonication }(3 \mathrm{~min}) \text { and manual } \\
& \text { shaking } \\
\text { - } & \text { Centrifugation }(10,000 \mathrm{rpm}, 3 \mathrm{~min}) \\
\text { - } & \text { Supernatant collected } \\
& \text { For blood samples, } 10 \mathrm{mg} \text { of } \mathrm{NaCl} \\
& \text { was added to break emulsion }\end{array}$ & & $1.5-2.5$ & $87.3-103.4$ & $\leq 3.5$ & \\
\hline $\begin{array}{c}\text { KET } \\
\text { NorKET }\end{array}$ & Urine & $0.5 \mathrm{~mL}$ & $\begin{array}{ll}\text { - } & \text { Centrifugation } \\
\text { - } & \text { Acid hydrolysis } \\
\text { - } & \text { DH adjustment } \\
& \text { Dilution }\end{array}$ & НТ-ВА $\mu \mathrm{E}$ & $\begin{array}{ll}\text { - } & \text { Sorbent: NVP-DVB } \\
& \text { Extraction: } 30 \mathrm{~min}(1800 \mathrm{rpm}) \mathrm{pH} \\
& 11.0 \\
& \text { LD: sonication with } 100 \mu \mathrm{L} \mathrm{MeOH} \\
& (15 \text { min })\end{array}$ & GC-MS & 1.0 & $84.9-105.0$ & $\leq 12.6$ & [223] \\
\hline
\end{tabular}

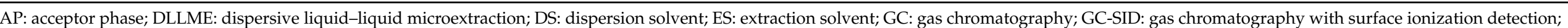

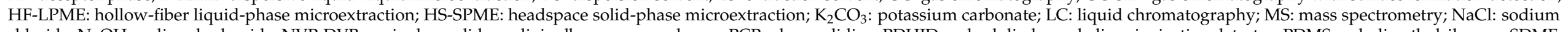

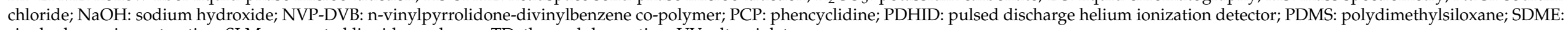
single-drop microextraction; SLM: supported liquid membrane; TD: thermal desorption; UV: ultraviolet. 


\section{Future Trends in the Forensic Context}

\subsection{New Psychoactive Substances (NPS)}

Nowadays, the illicit drug market has become more versatile than ever, where not only the classic drugs (i.e., cocaine, cannabis, heroin, etc.) are sold, but also NPS. Although some of these compounds are not really "new" since they were developed many decades ago, most $(<85 \%)$ appeared only in the last decade, being sold in smart shops and on the Internet as innocuous products designed "not for human consumption" [235]. A NPS is defined as "a new narcotic or psychotropic drug, in pure form or in preparation, that is not controlled by the United Nations drug conventions, but which may pose a public health threat" comparable to that substances listed in these conventions [236]. Many of them are traded as "legal" replacements to established controlled drugs such as cannabis, heroin, benzodiazepines, cocaine, amphetamines, and MDMA. In 2018, the number of NPS controlled by the EMCDDA reached a total of over 730 substances that have been detected in a wide range of different products, including synthetic cannabinoids, opioids, benzodiazepines, arylcyclohexylamines, synthetic cathinones, and phenethylamines. However, understanding the epidemiology of NPS remains poor. This includes problems with estimating the prevalence of use of new substances, which can be a complex and hard task because of the large number of substances and products that are available, but also because of the highly dynamic nature of the market. In many cases, individuals do not actually know what new substance they are using, while in other cases they may not even realize that they are using a new one. Therefore, the detection of NPS, and especially their metabolites in the forensic context, will remain a very hot topic for years to come. Figure 1a shows the number of applications for screening-controlled drugs in forensic matrices over the last quarter of a century, including opioids, cocaine, ATS, cannabinoids, hallucinogens, dissociative drugs, and NPS, and the figure highlights that monitoring the latter class of substances has grown in the last decade. For these reasons, several applications have been proposed for the analysis of NPS and related substances in the forensic context using innovative sample preparation approaches. Odoardi et al. [237] developed a comprehensive screening method for 78 substances in whole blood using DLLME combined with ultra-high-performance liquid chromatography coupled to tandem mass spectrometry (UHPLC-MS/MS). The results showed excellent recovery yields $(\sim 100 \%)$ with suitable inter-day repeatability levels $(<15 \%)$. The target analytes included cathinones, synthetic cannabinoids, phenethylamines, piperazines, KET, analogues, benzofurans, tryptamines, and some of their metabolites. The data showed that high recovery rates (up to $110 \%$ ) and low detection limits $(0.2 \mathrm{ng} / \mathrm{mL})$ were achieved. More recently, Bianchi et al. [238] combined MEPS and desorption electrospray ionization high-resolution mass spectrometry (DESI-HRMS) for the analysis of selected synthetic cathinones and cannabinoids in oral matrices. The results showed that good quantification limits were achieved $(0.25-0.5 \mathrm{mg} / \mathrm{L})$ using only $25 \mu \mathrm{L}$ of sample. Additionally, a very simple and effective $\mathrm{BA} \mu \mathrm{E}$-based approach was also proposed for the enrichment of mitragynine from urine samples, followed by liquid desorption and HPLC-DAD analysis [239]. Table 7 summarizes in detail the main miniaturized microextraction applications for the enrichment of NPS and related substances in forensic matrices, with emphasis on the key characteristics on the developed methodologies. Table S6 (Supplementary Material) contains additional information regarding other techniques for the determination of NPS in the forensic context $[99,100,128,131,143,197,219,238-246]$. 


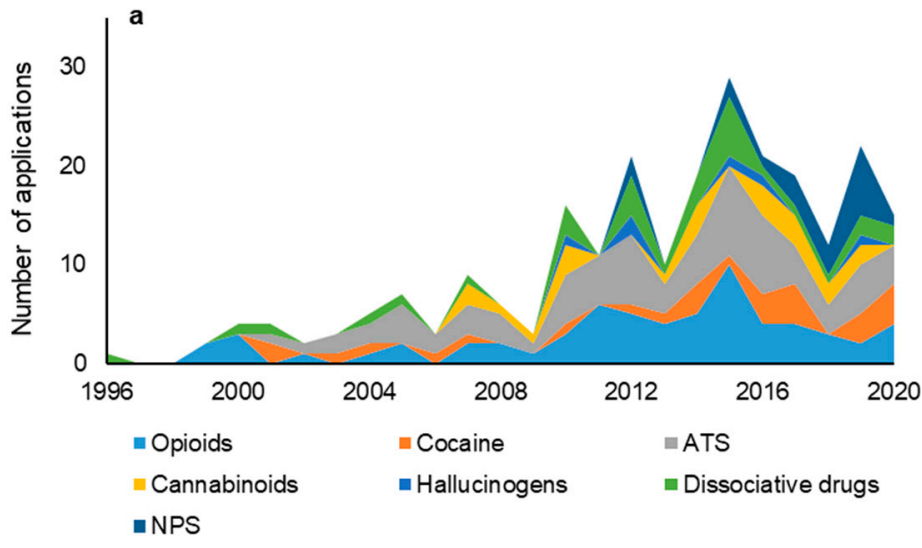

b

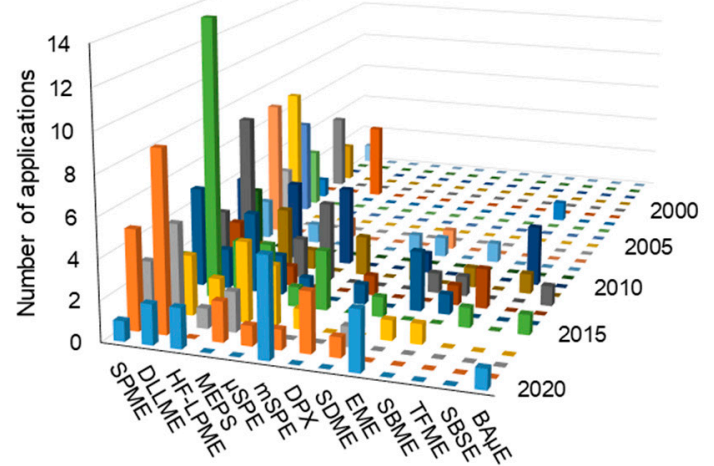

Figure 1. Number of applications for screening-controlled drugs in forensic matrices over the last quarter of century sorted by the type of priority substances (a) and microextraction-based techniques (b). The data reported for 2020 only includes published articles until the end of June. 
Table 7. Microextraction-based approaches for the analysis of new psychoactive substances (NPS) and related substances in the forensic matrix.

\begin{tabular}{|c|c|c|c|c|c|c|c|c|c|c|}
\hline Drugs & Matrix & $\begin{array}{c}\text { Sample } \\
\text { Amount }\end{array}$ & Sample Pretreatment & $\begin{array}{l}\text { Microextraction } \\
\text { Technique }\end{array}$ & $\begin{array}{c}\text { Optimized Experimental } \\
\text { Conditions }\end{array}$ & $\begin{array}{l}\text { Instrumental } \\
\text { System }\end{array}$ & $\begin{array}{l}\text { LOD } \\
(\mu \mathrm{g} / \mathrm{L})\end{array}$ & $\begin{array}{c}\text { Absolute } \\
\text { Recovery (\%) }\end{array}$ & $\begin{array}{l}\text { Precision } \\
(\%)\end{array}$ & Ref. \\
\hline $\begin{array}{c}\text { Synthetic cathinones } \\
\text { MPD } \\
\text { Synthetic cannabinoid } \\
\text { UR-144, JWH-250, JWH-200, } \\
\text { JWH-122, JWH- 019, AM-2201, } \\
\text { JWH-081, HU-211, CP47497 }\end{array}$ & Oral fluid & $0.025 \mathrm{~mL}$ & $\begin{array}{ll}\text { - } & \text { Dilution } \\
\text { - } & \text { Centrifugation } \\
& \text { pH adjustment }\end{array}$ & MEPS & $\begin{array}{ll}\text { - } & \text { Sorbent: } \mathrm{C} 18 \\
& \text { Conditioning: } 100 \mu \mathrm{L} \mathrm{MeOH}+ \\
& 100 \mu \mathrm{L} \mathrm{H}_{2} \mathrm{O} \\
& \text { Samples aspirated } \times 5(50 \mu \mathrm{L}) \\
\text { - } & \text { Elution: } 50 \mu \mathrm{L} \\
& \text { DCM } / \mathrm{IPA} / \mathrm{NH}_{4} \mathrm{OH} \times 25 \\
\text { - } & \text { Cleaning: } 50 \mu \mathrm{L} \times 10 \\
\end{array}$ & DESI-HRMS & $\begin{array}{l}0.25-0.5 \\
\mathrm{mg} / \mathrm{L} \\
\text { (LLOQ) }\end{array}$ & n.a. & $<19.4$ & [238] \\
\hline Mitragynine & Urine & $1 \mathrm{~mL}$ & - Dilution & ВА $\mu \mathrm{E}$ & $\begin{array}{ll}\text { - } & \text { Sorbent: NVP } \\
\text { - } & \text { Extraction: } 4 \mathrm{~h} \text { (1300 rpm), pH } 5.5 \\
& \text { Elution: } 200 \mu \mathrm{L} \text { MeOH/ACN } \\
& (1: 1, v: v) \text { under sonication (10 } \\
\text { min) }\end{array}$ & HPLC-DAD & 0.1 & 103 & $\leq 15$ & [239] \\
\hline $\begin{array}{c}\text { Synthetic cannabinoids } \\
\text { AM-2201, AM-2233, AM-694, } \\
\text { CB-13, JWH-007, JWH-019, } \\
\text { JWH-015, JWH-018, JWH-030, } \\
\text { JWH-03, JWH-081, JWH-098, } \\
\text { JWH-122, JWH-147, JWH-200, } \\
\text { JWH-201, JWH-250, JWH-251, } \\
\text { JWH-307, JWH-398, RCS4, } \\
\text { JWH-018 4OH indole, JWH- 018 } \\
\text { 5OH pentyl, JWH-018-COOH, } \\
\text { JWH-073 4OH butyl, JWH-073 } \\
\text { 5OH indole, JWH-073 COOH, } \\
\text { JWH-250 5OH pentyl } \\
\text { Synthetic cathinones4-FAMP, } \\
\text { 4-MEC, BL, BPD, CAT, EL, EPN, } \\
\text { HML, HMO, MBDB, MDAI, } \\
\text { MDPV, MPD, MD, ML, 4- MTA, } \\
\text { NM-2-AI, PD, PL } \\
\text { Piperaine derivatives } \\
\text { BZP, mCPP }\end{array}$ & Blood & $0.5 \mathrm{~mL}$ & $\begin{array}{ll}- & \text { Protein } \\
& \text { precipitation } \\
\text { - } & \text { Centrifugation } \\
\text { - } & \text { Dilution } \\
-\quad & \text { Salt addition } \\
\text { pH adjustment }\end{array}$ & DLLME & $\begin{array}{ll}- & \text { DS + ES: } 350 \mu \mathrm{L} \text { of } \\
& \mathrm{CHCl} / \mathrm{MeOH} 1: 2.5(\mathrm{v}: v), \\
\text { - } & \text { Rapid injection } \\
\text { - } & \text { Sonication (2 min) } \\
& \text { Centrifugation (4000 rpm,5 min) } \\
& \text { Infranatant collected, evaporated, } \\
& \text { and redissolved }\end{array}$ & UHPLC-MS/MS & 0.2 & 4-110 & n.a. & [237] \\
\hline
\end{tabular}

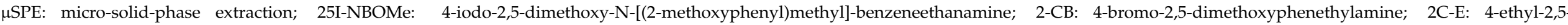

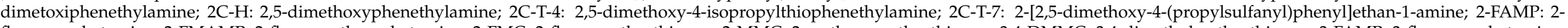

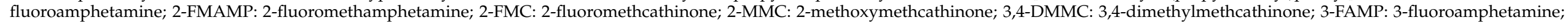

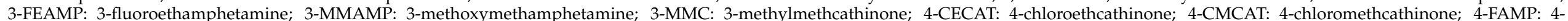

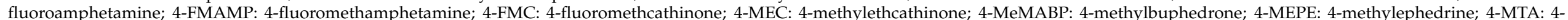

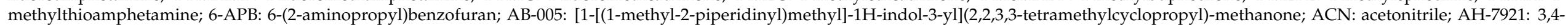

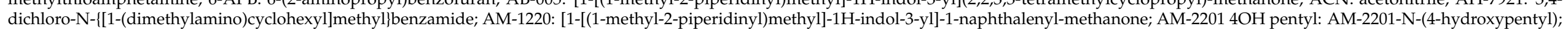

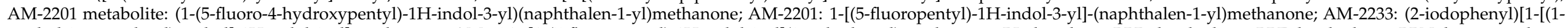

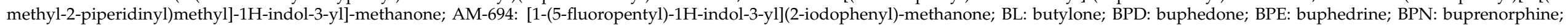

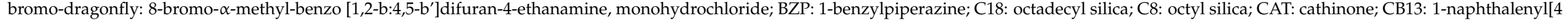

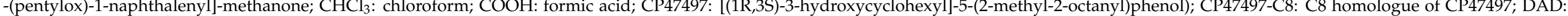

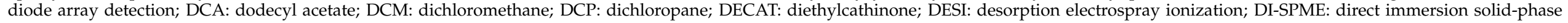

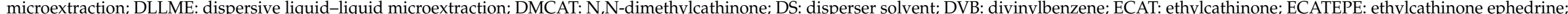

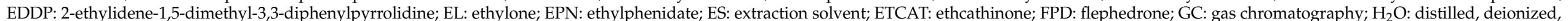




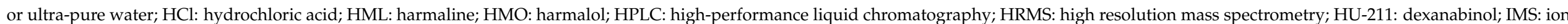

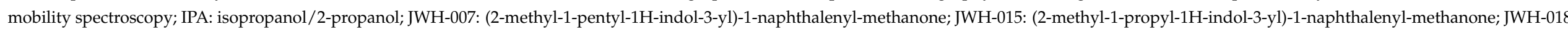

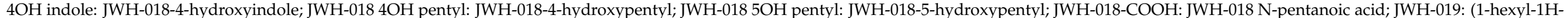

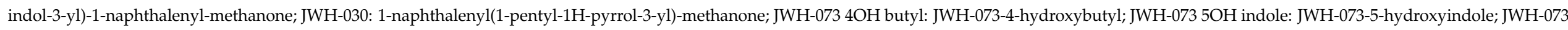

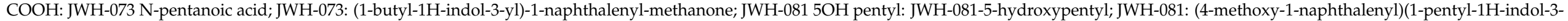

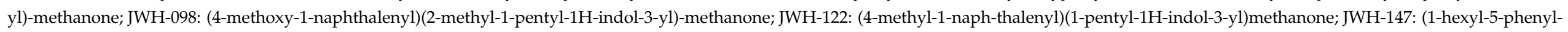

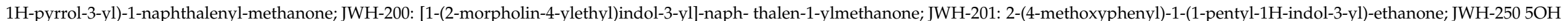

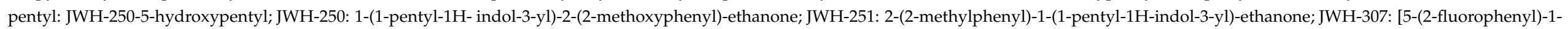

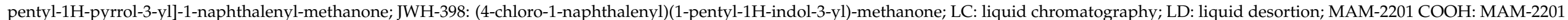

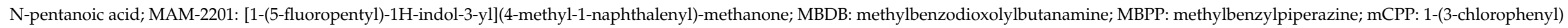

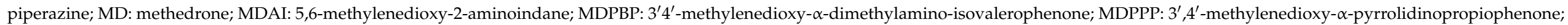

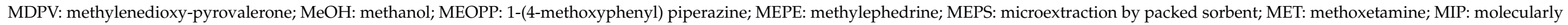

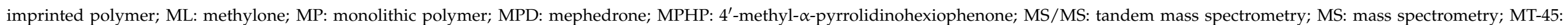

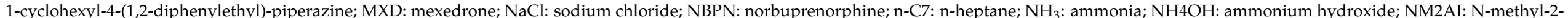

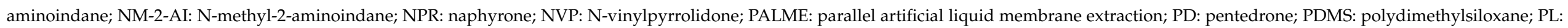

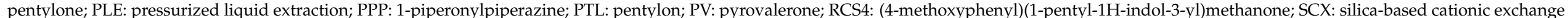

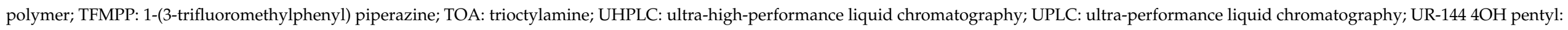

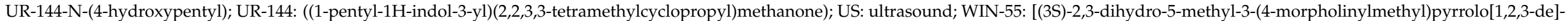

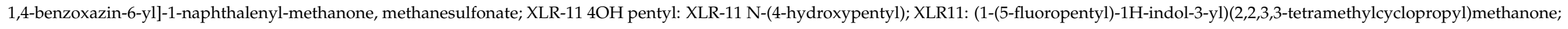
$\alpha$-PHP: $\alpha$-pyrrolidinohexiophenone; $\alpha$-PVP: $\alpha$-pyrrolidinopentiophenone. 


\subsection{Comparison of the Top-Eight Most Applied Microextraction-Based Techniques}

Miniaturized analytical techniques present many advantages over conventional sample preparation approaches. For this reason, they have been proposed in the last two decades for screening-controlled drugs in the forensic context, such as opioids and related compounds, cocaine, metabolites, ATS, cannabinoids, hallucinogens, dissociative drugs, and NPS. Figure $1 \mathrm{~b}$ shows the total number of applications dedicated for screeningcontrolled drugs in forensic matrices over the last two decades, sorted by the microextractionbased techniques. Most techniques are based on SPME, DLLME, HF-LPME, and MEPS, but also $\mu \mathrm{SPE}$ and $\mathrm{BA} \mu \mathrm{E}$ (among others); good examples can be consulted in the bibliography. From all these techniques, SPME and DLLME represent more than $50 \%$ of the miniaturized microextraction-based applications in the forensic context, and they were mostly applied to monitor opioids and ATS in biological matrices. Nonetheless, the other approaches have also gained some notoriety over the last few years, once they presented additional interesting characteristics. However, if we evaluate and compare the adequacy of the main characteristics of the top-eight most frequently applied microextraction techniques for screening-controlled drugs in the forensic context, several advantages and limitations can be noted, as summarized in Table 8 .

In any analytical framework, these relevant characteristics condition the sample preparation stage (whether it is user-friendly, environmentally acceptable, reusable, costeffective, and allows for routine work), the instrumental systems (whether the online coupling is possible and comprehensive), as well as the analytical performance (namely, if the enrichment factor, recovery yields, and level of precision are favored). In addition, the assessment of these characteristics is very important in particular for the beginners who intend to select and start to apply microextraction-based techniques for screening-controlled drugs in any forensic context. For instance, the sorbent-based microextraction techniques have been much more applied for screening-controlled drugs in the forensic context than the liquid-based ones, in which methodologies such as DLLME, HP-LPME, and SDME standing out mainly for their very low cost. Nevertheless, the sorbent-based techniques, such as SPME, SBSE, BA $\mu$ E, MEPS, and $\mu \mathrm{SPE}$, have been more widely employed since they present much more advantageous characteristics in any analytical framework. Even so, the passive or non-exhaustive sampling techniques (SPME, SBSE, and BA $\mu$ E) have been proposed more than the active or exhaustive sampling ones (MEPS and $\mu \mathrm{SPE}$ ), because they present interesting features.

Therefore, we can carry out a detailed analysis, as shown in Table 8, on the most relevant or "extremely suitable" $(+++)$ characteristics, presented by the main passive sorbent-based methodologies. In general, SPME is the most well-established microextraction technique, largely used in the forensic context, because it presents several advantages: it is an eco-friendly approach (i.e., a solventless or solvent-free process) and can be applied for routine work allowing for online coupling and automation, particularly with GC systems. On the other hand, SBSE and BA $\mu \mathrm{E}$ are user-friendly approaches that show great simplicity of handling. Furthermore, the former present wide reusability and high enrichment factors (such as SPME), whereas the latter is very cost-effective and comprehensive (like $\mu \mathrm{SPE}$ ), because it can be applied to a large number of classes of compounds having widened polarity and allows for coupling with both GC and HPLC systems. In addition to other distinct characteristics that it presents, the $\mathrm{BA} \mu \mathrm{E}$ devices can be lab-made, which is a remarkable advantage over the remaining sorbent-phase microextraction techniques. Furthermore, microextraction techniques such as $\mathrm{BA} \mu \mathrm{E}$ allow for the high-throughput approach $(\mathrm{HT}-\mathrm{BA} \mu \mathrm{E})$, which is an asset for the routine analytical work, as discussed before. 
Table 8. Comparison of the main characteristics of the top-eight most frequently applied microextraction-based techniques for screening-controlled drugs in the forensic context.

\begin{tabular}{|c|c|c|c|c|c|c|c|c|c|}
\hline \multirow[b]{3}{*}{$\begin{array}{l}\text { Analytical } \\
\text { Framework }\end{array}$} & \multirow[b]{3}{*}{ Characteristics } & \multicolumn{8}{|c|}{ Microextraction-Based Techniques } \\
\hline & & \multicolumn{5}{|c|}{ Sorbent-Phase } & \multicolumn{3}{|c|}{ Liquid-Phase } \\
\hline & & SPME & SBSE & $\mathrm{BA} \mu \mathrm{E}$ & MEPS & $\mu \mathrm{SPE}$ & DLLME & HP-LPME & SDME \\
\hline \multirow{4}{*}{$\begin{array}{c}\text { Sample } \\
\text { Preparation }\end{array}$} & User-friendly & ++ & +++ & +++ & + & + & ++ & + & + \\
\hline & Eco-friendly & +++ & ++ & ++ & + & + & ++ & + & ++ \\
\hline & Reusability & ++ & +++ & + & + & + & - & ++ & - \\
\hline & Routine work & +++ & ++ & ++ & + & + & + & + & + \\
\hline \multirow{2}{*}{$\begin{array}{c}\text { Instrumental } \\
\text { Systems }\end{array}$} & Online coupling & +++ & ++ & ++ & + & + & + & - & + \\
\hline & Comprehensive & ++ & ++ & +++ & + & +++ & + & ++ & + \\
\hline \multirow{3}{*}{ Performance } & Enrichment factor & +++ & +++ & ++ & + & + & + & ++ & ++ \\
\hline & Recovery yields & + & ++ & ++ & ++ & ++ & + & + & + \\
\hline & Precision level & ++ & ++ & ++ & + & + & + & ++ & + \\
\hline
\end{tabular}

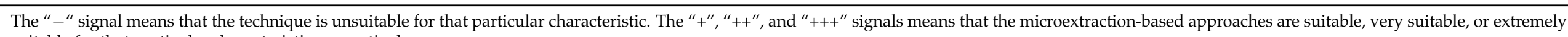
suitable for that particular characteristic, respectively. 


\section{Concluding Remarks}

The need for analytical methodologies that currently meet the high selectivity, sensitivity, and the principles of green analytical chemistry that are required by forensic science, pushes for the development of novel microextraction-based techniques.

Although the application of these techniques for screening-controlled drugs in forensic matrices is not yet very extensive, several works have shown that they are credible alternatives as analytical methodologies. Even so, these miniaturized techniques still need further improvement in clinical and toxicological context, although potential alternatives have shown several advantages in comparison to the well-established reference methods, because many of them allow for fast response in routine work. This is particularly important for the rapid detection of the increasing occurrence of NPS worldwide, since the development and implementation of faster alert systems is critical for legal and judicial authorities.

Supplementary Materials: The following are available online, Table S1: Microextraction-based approaches for the analysis of opioids and related substances in the forensic matrix, Table S2: Microextraction-based approaches for the analysis of cocaine and related substances in the forensic matrix, Table S3: Microextraction-based approaches for the analysis of amphetamine and related substances in the forensic matrix, Table S4: Microextraction-based approaches for the analysis of cannabinoids and related substances in the forensic matrix, Table S5: Microextraction-based approaches for the analysis of dissociative drugs and related substances in the forensic matrix, Table S6: Microextraction-based approaches for the analysis of new psychoactive substances (NPS) and related substances in the forensic matrix.

Author Contributions: Investigation, O.C.G. and M.N.O.; writing—original draft preparation, S.M.A.; writing-review and editing, N.R.N. and J.M.F.N.; supervision, J.M.F.N. All authors have read and agreed to the published version of the manuscript.

Funding: The authors thank Fundação para a Ciência e a Tecnologia (Portugal) for financial support (projects: UIDB/00100/2020 and UIDP/00100/2020), the PhD grant (SFRH/BD/107892/2015) and the contract established from DL 57/2016.

Institutional Review Board Statement: Not applicable.

Informed Consent Statement: Not applicable.

Data Availability Statement: Not applicable.

Acknowledgments: Not applicable.

Conflicts of Interest: The authors declare no conflict of interest. The funders had no role in the design of the study; in the collection, analyses, or interpretation of data; in the writing of the manuscript, or in the decision to publish the results.

Sample Availability: Not applicable.

\section{References}

1. United Nations Office on Drugs and Crime. World Drug Report 2016; United Nations Publication, Sales No. E.16.XI.7; United Nations: Vienna, Austria, 2016; ISBN 978-92-1-148286-7. eISBN: 978-92-1-057862-2.

2. European Monitoring Centre for Drugs and Drug Addiction. European Drug Report 2017: Trends and Developments; Publications Office of the European Union: Luxembourg, 2017.

3. United Nations Office on Drugs and Crime. World Drug Report 2017; United Nations Publication, Sales No. E.17.XI.6; United Nations: Vienna, Austria, 2017; ISBN 978-92-1-148291-1. eISBN 978-92-1-060623-3.

4. NICE. Controlled Drugs: Safe Use and Management (NG46). Clin. Guidel. 46. 2016. Available online: https://www.nice.org.uk/ guidance/ng46/resources / controlled-drugs-safe-use-and-management-pdf-1837456188613 (accessed on 24 June 2020).

5. Ganjali, M.R.; Sobhi, H.R.; Farahani, H.; Norouzi, P.; Dinarvand, R.; Kashtiaray, A. Solid drop based liquid-phase microextraction. J. Chromatogr. A 2010, 1217, 2337-2341. [CrossRef]

6. Chimuka, L.; Cukrowska, E.; Michel, M.; Buszewski, B. Advances in sample preparation using membrane-based liquid-phase microextraction techniques. TrAC Trends Anal. Chem. 2011, 30, 1781-1792. [CrossRef]

7. Kataoka, H. Recent developments and applications of microextraction techniques in drug analysis. Anal. Bioanal. Chem. 2010, 396, 339-364. [CrossRef] [PubMed] 
8. Vasconcelos, I.; Fernandes, C. Magnetic solid phase extraction for determination of drugs in biological matrices. TrAC Trends Anal. Chem. 2017, 89, 41-52. [CrossRef]

9. Raynie, D.E. Modern Extraction Techniques. Anal. Chem. 2006, 78, 3997-4004. [CrossRef] [PubMed]

10. Nogueira, J.M.F. Stir-bar sorptive extraction-15 years making sample preparation more environment friendly. TrAC Trends Anal. Chem. 2015, 71, 214-223. [CrossRef]

11. Barroso, M.; Gallardo, E.; Queiroz, J.A. The role of liquid-phase microextraction techniques in bioanalysis. Bioanalysis 2015, 7, 2195-2201. [CrossRef]

12. Lucena, R.; Cruz-Vera, M.; Cárdenas, S.; Valcárcel, M. Liquid-phase microextraction in bioanalytical sample preparation. Bioanalysis 2009, 1, 135-149. [CrossRef]

13. Moldoveanu, S.; David, R.V. Techniques, Modern Sample Preparation for Chromatography; Elsevier: Amesterdam, The Netherlands, 2015; ISBN 978-0-444-54319-6.

14. Pawliszyn, J. Handbook of Solid Phase Microextractionm; Development of SPME Devices and Coatings; Elsevier: Amesterdam, The Netherlands, 2012; pp. 61-97. ISBN 978-0-12-416017-0.

15. Getie-Kebtie, M.; Alterman, M. Sample Preparation in Biological Mass Spectrometry; Springer: Berlin, Germany, 2014; ISBN 978-94-007-0758-0.

16. Pawliszyn, J.; Lord, H.L. Handbook of Sample Preparation; John Wiley \& Sons: New York, NY, USA, 2011 ; ISBN 9780470099346.

17. Pawliszyn, J. Solid Phase Microextraction. In Headspace Analysis of Foods and Flavors; Rouseff, R.L., Cadwallader, K.R., Eds.; Advances in Experimental Medicine and Biology; Springer: Boston, MA, USA, 2001; Volume 488.

18. Lee, J.; Lee, H.K.; Rasmussen, K.E.; Pedersen-Bjergaard, S. Environmental and bioanalytical applications of hollow fiber membrane liquid-phase microextraction: A review. Anal. Chim. Acta 2008, 624, 253-268. [CrossRef]

19. Sarafraz-Yazdi, A.; Amiri, A. Liquid-phase microextraction. TrAC Trends Anal. Chem. 2010, 29, 1-14. [CrossRef]

20. Sharifi, V.; Abbasi, A.; Nosrati, A. Application of hollow fiber liquid phase microextraction and dispersive liquid-liquid microextraction techniques in analytical toxicology. J. Food Drug Anal. 2016, 24, 264-276. [CrossRef] [PubMed]

21. Han, D.; Row, K.H. Trends in liquid-phase microextraction, and its application to environmental and biological samples. Microchim. Acta 2012, 176, 1-22. [CrossRef]

22. Ghambarian, M.; Yamini, Y.; Esrafili, A. Developments in hollow fiber based liquid-phase microextraction: Principles and applications. Microchim. Acta 2012, 177, 271-294. [CrossRef]

23. Ocaña-González, J.A.; Fernández-Torres, R.; Bello-López, M.Á.; Ramos-Payán, M. New developments in microextraction techniques in bioanalysis. A review. Anal. Chim. Acta 2016, 905, 8-23. [CrossRef] [PubMed]

24. Farhadi, K.; Hatami, M.; Matin, A.A. Microextraction techniques in therapeutic drug monitoring. Biomed. Chromatogr. 2012, 26, 972-989. [CrossRef]

25. Alves, G.; Rodrigues, M.; Fortuna, A.; Falcão, A.; Queiroz, J. A critical review of microextraction by packed sorbent as a sample preparation approach in drug bioanalysis. Bioanalysis 2013, 5, 1409-1442. [CrossRef]

26. Moein, M.M.; Said, R.; Bassyouni, F.; Abdel-Rehim, M. Solid phase microextraction and related techniques for drugs in biological samples. J. Anal. Methods Chem. 2014, 2014. [CrossRef]

27. Płotka-Wasylka, J.; Szczepańska, N.; de la Guardia, M.; Namieśnik, J. Miniaturized solid-phase extraction techniques. TrAC Trends Anal. Chem. 2015, 73, 19-38. [CrossRef]

28. Spietelun, A.; Marcinkowski, Ł.; de la Guardia, M.; Namieśnik, J. Green aspects, developments and perspectives of liquid phase microextraction techniques. Talanta 2014, 119, 34-45. [CrossRef]

29. Pena-Pereira, F.; Lavilla, I.; Bendicho, C. Liquid-phase microextraction techniques within the framework of green chemistry. TrAC Trends Anal. Chem. 2010, 29, 617-628. [CrossRef]

30. Płotka-Wasylka, J.; Owczarek, K.; Namieśnik, J. Modern solutions in the field of microextraction using liquid as a medium of extraction. TrAC Trends Anal. Chem. 2016, 85, 46-64. [CrossRef]

31. Maisto, S.A.; Galizio, M.; Connors, G.J. Drug Use and Abuse; Cengage Learning: Belmont, CA, USA, 2011; ISBN 978-0-495-81441-2.

32. Kuhar, M.J.; Liddle, H. Drugs of Abuse; Marshall Cavendish Corporation: New York, NY, USA, 2012; ISBN 978-0-7614-7944-4.

33. United Nations Office on Drugs and Crime. The Non-Medical Use of Prescription Drugs; United Nations Office on Drugs and Crime: New York, NY, USA, 2011.

34. Isralowitz, R.E.; Meyers, P.L. Illicit Drugs; Greedwood: Oxford, UK, 2011; ISBN 978-0-313-36566-9.

35. Wong, R.C.; Tse, H.Y. Drugs of Abuse: Body Fluid Testing; Humana Press: Totowa, NJ, USA, 2005; ISBN 1-59259-951-6.

36. Sussman, S.; Ames, S.L. Drug Abuse: Concepts, Prevention, and Cessation; Cambridge University Press: Cambridge, UK, 2008; ISBN 978-0-521-85892-2.

37. Pates, R.; McBride, A.; Arnold, K. Injecting Illicit Drugs; Blackwell Publishing: Oxford: UK, 2005; ISBN 1-4051-1360-X.

38. Milone, M.C. Laboratory Testing for Prescription Opioids. J. Med. Toxicol. 2012, 8, 408-416. [CrossRef]

39. Smith, H.S. Opioid metabolism. Mayo Clin. Proc. 2009, 84, 613-624. [CrossRef]

40. Vlčková, H.; El-Beqqali, A.; Nováková, L.; Solich, P.; Abdel-Rehim, M. Determination of amphetamine and methadone in human urine by microextraction by packed sorbent coupled directly to mass spectrometry: An alternative for rapid clinical and forensic analysis. J. Sep. Sci. 2014, 37, 3306-3313. [CrossRef] [PubMed] 
41. Gonçalves, A.F.P.; Neng, N.R.; Mestre, A.S.; Carvalho, A.P.; Nogueira, J.M.F. Development of a powdered activated carbon in bar adsorptive micro-extraction for the analysis of morphine and codeine in human urine. J. Chromatogr. Sci. 2012, 50, 574-581. [CrossRef] [PubMed]

42. Ranjbari, E.; Golbabanezhad-Azizi, A.A.; Hadjmohammadi, M.R. Preconcentration of trace amounts of methadone in human urine, plasma, saliva and sweat samples using dispersive liquid-liquid microextraction followed by high performance liquid chromatography. Talanta 2012, 94, 116-122. [CrossRef] [PubMed]

43. Habibi-Khorasani, M.; Mohammadpour, A.H.; Mohajeri, S.A. Development of solid-phase microextraction coupled with liquid chromatography for analysis of tramadol in brain tissue using its molecularly imprinted polymer. Biomed. Chromatogr. 2017, 31, 1-11. [CrossRef]

44. Mohammadiazar, S.; Hasanli, F.; Maham, M.; Payami Samarin, S. Solid-phase microextraction of methadone in urine samples by electrochemically co-deposited sol-gel/Cu nanocomposite fiber. Biomed. Chromatogr. 2017, 31, 1-7. [CrossRef]

45. Ara, K.M.; Raofie, F. Low-voltage electrochemically stimulated stir membrane liquid-liquid microextraction as a novel technique for the determination of methadone. Talanta 2017, 168, 105-112. [CrossRef]

46. Lamei, N.; Ezoddin, M.; Abdi, K. Air assisted emulsification liquid-liquid microextraction based on deep eutectic solvent for preconcentration of methadone in water and biological samples. Talanta 2017, 165, 176-181. [CrossRef]

47. El-Beqqali, A.; Abdel-Rehim, M. Molecularly imprinted polymer-sol-gel tablet toward micro-solid phase extraction: I. Determination of methadone in human plasma utilizing liquid chromatography-tandem mass spectrometry. Anal. Chim. Acta 2016, 936, 116-122. [CrossRef]

48. Taghvimi, A.; Hamishehkar, H.; Ebrahimi, M. Development and validation of a magnetic solid-phase extraction with highperformance liquid chromatography method for the simultaneous determination of amphetamine and methadone in urine. J. Sep. Sci. 2016, 39, 2307-2312. [CrossRef]

49. Taheri, S.; Jalali, F.; Fattahi, N.; Jalili, R.; Bahrami, G. Sensitive determination of methadone in human serum and urine by dispersive liquid-liquid microextraction based on the solidification of a floating organic droplet followed by HPLC-UV. J. Sep. Sci. 2015, 38, 3545-3551. [CrossRef] [PubMed]

50. Khoubnasabjafari, M.; Ansarin, K.; Jouyban-Gharamaleki, V.; Panahi-Azar, V.; Shayanfar, A.; Mohammadzadeh, L.; Jouyban, A.G. Extraction and analysis of methadone in exhaled breath condensate using a validated LC-UV method. J. Pharm. Pharm. Sci. 2015, 18, 207-219. [CrossRef] [PubMed]

51. Ebrahimzadeh, H.; Mirbabaei, F.; Asgharinezhad, A.A.; Shekari, N.; Mollazadeh, N. Optimization of solvent bar microextraction combined with gas chromatography for preconcentration and determination of methadone in human urine and plasma samples. J. Chromatogr. B Anal. Technol. Biomed. Life Sci. 2014, 947-948, 75-82. [CrossRef] [PubMed]

52. Rodriguez-Lafuente, A.; Mirnaghi, F.S.; Pawliszyn, J. Determination of cocaine and methadone in urine samples by thin-film solid-phase microextraction and direct analysis in real time (DART) coupled with tandem mass spectrometry Anti-doping Analysis. Anal. Bioanal. Chem. 2013, 405, 9723-9727. [CrossRef] [PubMed]

53. Saracino, M.A.; Marcheselli, C.; Somaini, L.; Pieri, M.C.; Gerra, G.; Ferranti, A.; Raggi, M.A. A novel test using dried blood spots for the chromatographic assay of methadone. Anal. Bioanal. Chem. 2012, 404, 503-511. [CrossRef] [PubMed]

54. Ebrahimzadeh, H.; Mehdinia, A.; Kamarei, F.; Moradi, E. A sensitive method for the determination of methadone in biological samples using nano-structured $\alpha$-carboxy polypyrrol as a sorbent of SPME. Chromatographia 2012, 75, 149-155. [CrossRef]

55. Ebrahimzadeh, H.; Khezri, E.; Kamarei, F. Determination of methadone in biological samples using liquid phase microextraction with back extraction combined with LC. Chromatographia 2010, 72, 231-238. [CrossRef]

56. El-Beqqali, A.; Abdel-Rehim, M. Quantitative analysis of methadone in human urine samples by microextraction in packed syringe-gas chromatography-mass spectrometry (MEPS-GC-MS). J. Sep. Sci. 2007, 30, 2501-2505. [CrossRef]

57. dos Santos Lucas, A.C.; Bermejo, A.; Fernández, P.; Tabernero, M.J. Solid-Phase Microextraction in the Determination of Methadone in Human Saliva by Gas Chromatography-Mass Spectrometry. J. Anal. Toxicol. 2000, 24, 93-96. [CrossRef]

58. Lucas, A.C.S.; Bermejo, A.M.; Tabernero, M.J.; Fernández, P.; Strano-Rossi, S. Use of solid-phase microextraction (SPME) for the determination of methadone and EDDP in human hair by GC-MS. Forensic Sci. Int. 2000, 107, 225-232. [CrossRef]

59. Bermejo, A.M.; Seara, R.; Dos Santos Lucas, A.C.; Tabernero, M.J.; Fernández, P.; Marsili, R. Use of solid-phase microextraction (SPME) for the determination of methadone and its main metabolite, EDDP, in plasma by gas chromatography-mass spectrometry. J. Anal. Toxicol. 2000, 24, 66-69. [CrossRef] [PubMed]

60. Sporkert, F.; Pragst, F. Determination of methadone and its metabolites EDDP and EMDP in human hair by headspace solid-phase microextraction and gas chromatography-mass spectrometry. J. Chromatogr. B Biomed. Sci. Appl. 2000, 746, 255-264. [CrossRef]

61. Myung, S.-W.; Kim, S.; Park, J.-H.; Kim, M.; Lee, J.-C.; Kim, T.-J. Solid-phase microextraction for the determination of pethidine and methadone in human urine using gas chromatography with nitrogen-phosphorus detection. Analyst 1999, 124, 1283-1286. [CrossRef]

62. Abbasian, M.; Balali-Mood, M.; Mozaffari, S.A.; Amoli, H.S. Solid-phase microextraction of ultra-trace amounts of tramadol from human urine by using a carbon nanotube/flower-shaped zinc oxide hollow fiber. J. Sep. Sci. 2016, 39, 4449-4457. [CrossRef]

63. Habibollahi, S.; Tavakkoli, N.; Nasirian, V.; Khani, H. Determination of Tramadol by Dispersive Liquid-Liquid Microextraction Combined with GC-MS. J. Chromatogr. Sci. 2015, 655-661. [CrossRef] 
64. Ebrahimzadeh, H.; Mollazadeh, N.; Asgharinezhad, A.A.; Shekari, N.; Mirbabaei, F. Multivariate optimization of surfactantassisted directly suspended droplet microextraction combined with GC for the preconcentration and determination of tramadol in biological samples. J. Sep. Sci. 2013, 36, 3783-3790. [CrossRef]

65. Kiarostami, V.; Rouini, M.-R.; Mohammadian, R.; Lavasani, H.; Ghazaghi, M. Binary Solvents Dispersive Liquid-Liquid Microextraction (BS-DLLME) Method for Determination of Tramadol in Urine Using High-Performance Liquid Chromatography. DARU J. Pharm. Sci. 2014, 22, 25. [CrossRef]

66. Mirmahdieh, S.; Khayamian, T. Electrospun nanofibers of poly(methylmethacrylate)/polystyrene blend as a microcolumn extraction sorbent followed by corona discharge ion mobility spectrometry for analysis of tramadol in biological fluids. Chromatographia 2013, 76, 541-548. [CrossRef]

67. Ghasemi, E. Optimization of solvent bar microextraction combined with gas chromatography mass spectrometry for preconcentration and determination of tramadol in biological samples. J. Chromatogr. A 2012, 1251, 48-53. [CrossRef]

68. Ghambarian, M.; Yamini, Y.; Esrafili, A. Three-phase hollow fiber liquid-phase microextraction based on two immiscible organic solvents for determination of tramadol in urine and plasma samples. J. Pharm. Biomed. Anal. 2011, 56, 1041-1045. [CrossRef]

69. Ebrahimzadeh, H.; Yamini, Y.; Sedighi, A.; Rouini, M.R. Determination of tramadol in human plasma and urine samples using liquid phase microextraction with back extraction combined with high performance liquid chromatography. J. Chromatogr. B Anal. Technol. Biomed. Life Sci. 2008, 863, 229-234. [CrossRef] [PubMed]

70. Sha, Y.F.; Shen, S.; Duan, G.L. Rapid determination of tramadol in human plasma by headspace solid-phase microextraction and capillary gas chromatography-mass spectrometry. J. Pharm. Biomed. Anal. 2005, 37, 143-147. [CrossRef] [PubMed]

71. Ahmar, H.; Tabani, H.; Hossein Koruni, M.; Davarani, S.S.H.; Fakhari, A.R. A new platform for sensing urinary morphine based on carrier assisted electromembrane extraction followed by adsorptive stripping voltammetric detection on screen-printed electrode. Biosens. Bioelectron. 2014, 54, 189-194. [CrossRef] [PubMed]

72. Boojaria, A.; Masrournia, M.; Ghorbani, H.; Ebrahimitalab, A.; Miandarhoie, M. Silane modified magnetic nanoparticles as a novel adsorbent for determination of morphine at trace levels in human hair samples by high-performance liquid chromatography with diode array detection. Forensic Sci. Med. Pathol. 2015, 11, 497-503. [CrossRef] [PubMed]

73. Moller, M.; Aleksa, K.; Walasek, P.; Karaskov, T.; Koren, G. Solid-phase microextraction for the detection of codeine, morphine and 6-monoacetylmorphine in human hair by gas chromatography-mass spectrometry. Forensic Sci. Int. 2010, 196, 64-69. [CrossRef]

74. Yamini, Y.; Pourali, A.; Seidi, S.; Rezazadeh, M. Electromembrane extraction followed by high performance liquid chromatography: An efficient method for extraction and determination of morphine, oxymorphone, and methylmorphine from urine samples. Anal. Methods 2014, 6, 5554. [CrossRef]

75. Somaini, L.; Saracino, M.A.; Marcheselli, C.; Zanchini, S.; Gerra, G.; Raggi, M.A. Combined liquid chromatography-coulometric detection and microextraction by packed sorbent for the plasma analysis of long acting opioids in heroin addicted patients. Anal. Chim. Acta 2011, 702, 280-287. [CrossRef]

76. Gardner, M.A.; Sampsel, S.; Jenkins, W.W.; Owens, J.E. Analysis of fentanyl in urine by DLLME-GC-MS. J. Anal. Toxicol. 2015, 39, 118-125. [CrossRef]

77. Bagheri, H.; Piri-Moghadam, H.; Bayat, P.; Balalaie, S. Application of sol-gel based molecularly imprinted xerogel for on-line capillary microextraction of fentanyl from urine and plasma samples. Anal. Methods 2013, 5, 7096. [CrossRef]

78. Wang, C.; Li, E.; Xu, G.; Wang, H.; Gong, Y.; Li, P.; Liu, S.; He, Y. Determination of fentanyl in human breath by solid-phase microextraction and gas chromatography-mass spectrometry. Microchem. J. 2009, 91, 149-152. [CrossRef]

79. Ebrahimzadeh, H.; Yamini, Y.; Gholizade, A.; Sedighi, A.; Kasraee, S. Determination of fentanyl in biological and water samples using single-drop liquid-liquid-liquid microextraction coupled with high-performance liquid chromatography. Anal. Chim. Acta 2008, 626, 193-199. [CrossRef] [PubMed]

80. Bagheri, H.; Es-haghi, A.; Khalilian, F.; Rouini, M.R. Determination of fentanyl in human plasma by head-space solid-phase microextraction and gas chromatography-mass spectrometry. J. Pharm. Biomed. Anal. 2007, 43, 1763-1768. [CrossRef] [PubMed]

81. Dufresne, C.; Favetta, P.; Gonin, R.; Bureau, J.; Guitton, J. Simultaneous Determination of Fentanyl and Midazolam in Plasma Using Direct Solid-Phase Microextraction Before Gas Chromatography-Mass Spectrometry Analysis. Anal. Lett. 2002, 35, 1575-1590. [CrossRef]

82. Saraji, M.; Khalili Boroujeni, M.; Hajialiakbari Bidgoli, A.A. Comparison of dispersive liquid-liquid microextraction and hollow fiber liquid-liquid-liquid microextraction for the determination of fentanyl, alfentanil, and sufentanil in water and biological fluids by high-performance liquid chromatography. Anal. Bioanal. Chem. 2011, 400, 2149-2158. [CrossRef]

83. Hashemian, Z.; Khayamian, T.; Saraji, M. Anticodeine aptamer immobilized on a Whatman cellulose paper for thin-film microextraction of codeine from urine followed by electrospray ionization ion mobility spectrometry. Anal. Bioanal. Chem. 2015, 407, 1615-1623. [CrossRef]

84. Seyyal, E.; Evans-Nguyen, T. Online Sol-gel Capillary Microextraction-Mass Spectrometry (CME-MS) Analysis of Illicit Drugs. J. Am. Soc. Mass Spectrom. 2019, 30, 595-604. [CrossRef]

85. Riahi-Zanjani, B.; Balali-Mood, M.; Es'haghi, Z.; Asoodeh, A.; Ghorani-Azam, A. Molecular modeling and experimental study of a new peptide-based microextraction fiber for preconcentrating morphine in urine samples. J. Mol. Model. 2019, 25. [CrossRef]

86. Alahyari, E.; Setareh, M.; Shekari, A.; Roozbehani, G.; Soltaninejad, K. Analysis of opioids in postmortem urine samples by dispersive liquid-liquid microextraction and high performance liquid chromatography with photo diode array detection. Egypt. J. Forensic Sci. 2018, 8. [CrossRef] 
87. Riahi-Zanjani, B.; Balali-Mood, M.; Asoodeh, A.; Es'haghi, Z.; Ghorani-Azam, A. Developing a new sensitive solid-phase microextraction fiber based on carbon nanotubes for preconcentration of morphine. Appl. Nanosci. 2018, 8, 2047-2056. [CrossRef]

88. Dehnavi, F.; Dadfarnia, S.; Shabani, A.M.H.; Babaei, A. Dispersive Liquid-Liquid Microextraction Based on Solidification of Floating Organic Drop for Isolation and Determination of Opium Alkaloids. J. Anal. Chem. 2018, 73, 765-770. [CrossRef]

89. Gentili, S.; Mortali, C.; Mastrobattista, L.; Berretta, P.; Zaami, S. Determination of different recreational drugs in sweat by headspace solid-phase microextraction gas chromatography mass spectrometry (HS-SPME GC/MS): Application to drugged drivers. J. Pharm. Biomed. Anal. 2016, 129, 282-287. [CrossRef] [PubMed]

90. Fisichella, M.; Odoardi, S.; Strano-Rossi, S. High-throughput dispersive liquid/liquid microextraction (DLLME) method for the rapid determination of drugs of abuse, benzodiazepines and other psychotropic medications in blood samples by liquid chromatography-tandem mass spectrometry (LC-MS/MS) and app. Microchem. J. 2015, 123, 33-41. [CrossRef]

91. Montesano, C.; Simeoni, M.C.; Curini, R.; Sergi, M.; Lo Sterzo, C.; Compagnone, D. Determination of illicit drugs and metabolites in oral fluid by microextraction on packed sorbent coupled with LC-MS/MS. Anal. Bioanal. Chem. 2015, 407, 3647-3658. [CrossRef]

92. Meng, L.; Zhang, W.; Meng, P.; Zhu, B.; Zheng, K. Comparison of hollow fiber liquid-phase microextraction and ultrasoundassisted low-density solvent dispersive liquid-liquid microextraction for the determination of drugs of abuse in biological samples by gas chromatography-mass spectrometry. J. Chromatogr. B Anal. Technol. Biomed. Life Sci. 2015, 989, 46-53. [CrossRef] [PubMed]

93. Kohler, I.; Schappler, J.; Sierro, T.; Rudaz, S. Dispersive liquid-liquid microextraction combined with capillary electrophoresis and time-of-flight mass spectrometry for urine analysis. J. Pharm. Biomed. Anal. 2013, 73, 82-89. [CrossRef]

94. Stege, P.W.; Lapierre, A.V.; Martinez, L.D.; Messina, G.A.; Sombra, L.L. A combination of single-drop microextraction and open tubular capillary electrochromatography with carbon nanotubes as stationary phase for the determination of low concentration of illicit drugs in horse urine. Talanta 2011, 86, 278-283. [CrossRef]

95. Chen, M.L.; Suo, L.L.; Gao, Q.; Feng, Y.Q. Determination of eight illegal drugs in human urine by combination of magnetic solid-phase extraction with capillary zone electrophoresis. Electrophoresis 2011, 32, 2099-2106. [CrossRef]

96. Merola, G.; Gentili, S.; Tagliaro, F.; MacChia, T. Determination of different recreational drugs in hair by HS-SPME and GC/MS. Anal. Bioanal. Chem. 2010, 397, 2987-2995. [CrossRef]

97. Strano-Rossi, S.; Molaioni, F.; Botrè, F. Application of solid-phase microextraction to antidoping analysis: Determination of stimulants, narcotics, and other classes of substances excreted free in urine. J. Anal. Toxicol. 2005, 29, 217-222. [CrossRef]

98. Gentili, S.; Cornetta, M.; Macchia, T. Rapid screening procedure based on headspace solid-phase microextraction and gas chromatography-mass spectrometry for the detection of many recreational drugs in hair. J. Chromatogr. B Anal. Technol. Biomed. Life Sci. 2004, 801, 289-296. [CrossRef]

99. Fernández, P.; Regenjo, M.; Ares, A.; Fernández, A.M.; Lorenzo, R.A.; Carro, A.M. Simultaneous determination of 20 drugs of abuse in oral fluid using ultrasound-assisted dispersive liquid-liquid microextraction. Anal. Bioanal. Chem. 2019, 411, 193-203. [CrossRef] [PubMed]

100. Vincenti, F.; Montesano, C.; Cellucci, L.; Gregori, A.; Fanti, F.; Compagnone, D.; Curini, R.; Sergi, M. Combination of pressurized liquid extraction with dispersive liquid liquid micro extraction for the determination of sixty drugs of abuse in hair. J. Chromatogr. A 2019, 1605, 360348. [CrossRef] [PubMed]

101. Rahimi, A.; Nojavan, S.; Tabani, H. Inside gel electromembrane extraction: A novel green methodology for the extraction of morphine and codeine from human biological fluids. J. Pharm. Biomed. Anal. 2020, 184, 113175. [CrossRef] [PubMed]

102. Adlnasab, L.; Shahdousti, P.; Ahmar, H. Layered double hydroxide intercalated with tyrosine for ultrasonic-assisted microextraction of tramadol and methadone from biological samples followed by GC/MS analysis. Microchim. Acta 2020, 187, 265. [CrossRef]

103. Shekari, A.; Forouzesh, M.; Valipour, R.; Fallah, F.; Shojaei, P. Validation and Optimization of Ultrasound-Assisted Dispersive Liquid- Liquid Microextraction as a Preparation Method for Detection of Methadone in Saliva with Gas Chromatography-Mass Spectrometry Technique. Adv. Pharm. Bull. 2020, 10, 329-333. [CrossRef]

104. Lu, Q.; Guo, H.; Zhang, Y.; Tang, X.; Lei, W.; Qi, R.; Chu, J.; Li, D.; Zhao, Q. Talanta Graphene oxide-Fe 3 O 4 nanocomposite magnetic solid phase extraction followed by UHPLC-MS / MS for highly sensitive determination of eight psychoactive drugs in urine samples. Talanta 2020, 206, 120212. [CrossRef]

105. Mirzaei, F.; Fakhari, A.R.; Hashemzadeh, A.; Amini, M.M. Sensitive determination of ketamine, methylphenidate, and tramadol in urine and wastewater samples by Porous Aromatic Framework-48 assisted electromembrane extraction coupled with ion mobility spectrometer. Int. J. Ion Mobil. Spectrom. 2020, 23, 29-37. [CrossRef]

106. Karch, S.B. Drug Abuse Handbook; CRC Press: New York, NY, USA, 1997; ISBN 0-8493-2637-0.

107. Karch, S.B. Cocaine: History, use, abuse. J. R. Soc. Med. 1999, 92, 393-397. [CrossRef]

108. Goldstein, R.A.; DesLauriers, C.; Burda, A.; Johnson-Arbor, K. Cocaine: History, social implications, and toxicity: A review. Semin. Diagn. Pathol. 2009, 26, 10-17. [CrossRef]

109. World Drug Report 2018; United Nations publication, Sales No. E.18.XI.9; United Nations: Vienna, Austria, 2018; ISBN 978-92-1148304-8. ISBN: 978-92-1-045058-4.

110. European Monitoring Centre for Drugs and Drug Addiction. European Drug Report 2018: Trends and Developments; Publications Office of the European Union: Luxembourg, 2018.

111. Rosado, T.; Gonçalves, A.; Margalho, C.; Barroso, M.; Gallardo, E. Rapid analysis of cocaine and metabolites in urine using microextraction in packed sorbent and GC/MS. Anal. Bioanal. Chem. 2017, 409, 2051-2063. [CrossRef] 
112. Silveira, G.d.; Belitsky, Í.T.; Loddi, S.; de Oliveira, C.D.R.; Zucoloto, A.D.; Fruchtengarten, L.V.G.; Yonamine, M. Development of a method for the determination of cocaine, cocaethylene and norcocaine in human breast milk using liquid phase microextraction and gas chromatography-mass spectrometry. Forensic Sci. Int. 2016, 265, 22-28. [CrossRef] [PubMed]

113. Sánchez-González, J.; Barreiro-Grille, T.; Cabarcos, P.; Tabernero, M.J.; Bermejo-Barrera, P.; Moreda-Piñeiro, A. Magnetic molecularly imprinted polymer based-Micro-solid phase extraction of cocaine and metabolites in plasma followed by high performance liquid chromatography-Tandem mass spectrometry. Microchem. J. 2016, 127, 206-212. [CrossRef]

114. Yang, F.; Zou, Y.; Ni, C.; Wang, R.; Wu, M.; Liang, C.; Zhang, J.; Yuan, X.; Liu, W. Magnetic dispersive solid-phase extraction based on modified magnetic nanoparticles for the detection of cocaine and cocaine metabolites in human urine by HPLC-MS. J. Sep. Sci. 2017, 40. [CrossRef] [PubMed]

115. Cocovi-Solberg, D.J.; Esteve-Turrillas, F.A.; Armenta, S.; de la Guardia, M.; Miró, M. Towards an automatic lab-on-valve-ion mobility spectrometric system for detection of cocaine abuse. J. Chromatogr. A 2017, 1512, 43-50. [CrossRef] [PubMed]

116. Pego, A.M.F.; Roveri, F.L.; Kuninari, R.Y.; Leyton, V.; Miziara, I.D.; Yonamine, M. Determination of cocaine and its derivatives in hair samples by liquid phase microextraction (LPME) and gas chromatography-mass spectrometry (GC-MS). Forensic Sci. Int. 2017, 274, 83-90. [CrossRef]

117. Sánchez-González, J.; García-Carballal, S.; Cabarcos, P.; Tabernero, M.J.; Bermejo-Barrera, P.; Moreda-Piñeiro, A. Determination of cocaine and its metabolites in plasma by porous membrane-protected molecularly imprinted polymer micro-solid-phase extraction and liquid chromatography-tandem mass spectrometry. J. Chromatogr. A 2016, 1451, 15-22. [CrossRef] [PubMed]

118. Sánchez-González, J.; Tabernero, M.J.; Bermejo, A.M.; Bermejo-Barrera, P.; Moreda-Piñeiro, A. Porous membrane-protected molecularly imprinted polymer micro-solid-phase extraction for analysis of urinary cocaine and its metabolites using liquid chromatography - Tandem mass spectrometry. Anal. Chim. Acta 2015, 898, 50-59. [CrossRef]

119. Fucci, N.; Gambelunghe, C.; Aroni, K.; Rossi, R. A direct immersion solid-phase microextraction gas chromatography/mass spectrometry method for the simultaneous detection of levamisole and minor cocaine congeners in hair samples from chronic abusers. Ther. Drug Monit. 2014, 36, 789-795. [CrossRef] [PubMed]

120. Yamini, Y.; Seidi, S.; Feizbakhsh, R.; Baheri, T.; Rezazadeh, M. Liquid-phase microextraction based on two immiscible organic solvents followed by gas chromatography with mass spectrometry as an efficient method for the preconcentration and determination of cocaine, ketamine, and lidocaine in human urine samples. J. Sep. Sci. 2014, 37, 2364-2371. [CrossRef] [PubMed]

121. Mozaner Bordin, D.C.; Alves, M.N.R.; Cabrices, O.G.; de Campos, E.G.; De Martinis, B.S. A Rapid Assay for the Simultaneous Determination of Nicotine, Cocaine and Metabolites in Meconium Using Disposable Pipette Extraction and Gas ChromatographyMass Spectrometry (GC-MS). J. Anal. Toxicol. 2014, 38, 31-38. [CrossRef] [PubMed]

122. Álvarez, I.; Bermejo, A.M.; Tabernero, M.J.; Fernández, P.; López, P. Determination of cocaine and cocaethylene in plasma by solid-phase microextraction and gas chromatography-mass spectrometry. J. Chromatogr. B Anal. Technol. Biomed. Life Sci. 2007, 845, 90-94. [CrossRef] [PubMed]

123. Bermejo, A.M.; López, P.; Álvarez, I.; Tabernero, M.J.; Fernández, P. Solid-phase microextraction for the determination of cocaine and cocaethylene in human hair by gas chromatography-mass spectrometry. Forensic Sci. Int. 2006, 156, 2-8. [CrossRef]

124. Follador, M.J.D.; Yonamine, M.; Moreau, R.L.D.M.; Silva, O.A. Detection of cocaine and cocaethylene in sweat by solid-phase microextraction and gas chromatography/mass spectrometry. J. Chromatogr. B Anal. Technol. Biomed. Life Sci. 2004, 811, 37-40. [CrossRef]

125. Pereira De Toledo, F.C.; Yonamine, M.; De Moraes Moreau, R.L.; Silva, O.A. Determination of cocaine, benzoylecgonine and cocaethylene in human hair by solid-phase microextraction and gas chromatography-mass spectrometry. J. Chromatogr. B Anal. Technol. Biomed. Life Sci. 2003, 798, 361-365. [CrossRef]

126. de Jager, L.S.; Andrews, A.R. Development of a screening method for cocaine and cocaine metabolites in urine using solvent microextraction in conjunction with gas chromatography. J. Chromatogr. A 2001, 911, 97-105. [CrossRef]

127. de Jager, L.S.; Andrews, A.R.J. Preliminary studies of a fast screening method for cocaine and cocaine metabolites in urine using hollow fibre membrane solvent microextraction (HFMSME). Analyst 2001, 126, 1298-1303. [CrossRef]

128. Ares, A.M.; Fernández, P.; Regenjo, M.; Fernández, A.M.; Carro, A.M.; Lorenzo, R.A. A fast bioanalytical method based on microextraction by packed sorbent and UPLC-MS/MS for determining new psychoactive substances in oral fluid. Talanta 2017, 174, 454-461. [CrossRef]

129. Sergi, M.; Compagnone, D.; Curini, R.; D’Ascenzo, G.; Del Carlo, M.; Napoletano, S.; Risoluti, R. Micro-solid phase extraction coupled with high-performance liquid chromatography-tandem mass spectrometry for the determination of stimulants, hallucinogens, ketamine and phencyclidine in oral fluids. Anal. Chim. Acta 2010, 675, 132-137. [CrossRef]

130. Napoletano, S.; Montesano, C.; Compagnone, D.; Curini, R.; D’Ascenzo, G.; Roccia, C.; Sergi, M. Determination of illicit drugs in urine and plasma by micro-SPE followed by HPLC-MS/MS. Chromatographia 2012, 75, 55-63. [CrossRef]

131. Sorribes-Soriano, A.; Valencia, A.; Esteve-Turrillas, F.A.; Armenta, S.; Herrero-Martínez, J.M. Development of pipette tip-based poly(methacrylic acid-co-ethylene glycol dimethacrylate) monolith for the extraction of drugs of abuse from oral fluid samples. Talanta 2019, 205, 120158. [CrossRef] [PubMed]

132. Sousa, D.V.M.; Pereira, F.V.; Nascentes, C.C.; Moreira, J.S.; Boratto, V.H.M.; Orlando, R.M. Cellulose cone tip as a sorbent material for multiphase electrical field- assisted extraction of cocaine from saliva and determination by LC-MS / MS. Talanta 2020, 208, 120353. [CrossRef] 
133. Lizot, L.D.L.F.; da Silva, A.C.C.; Bastiani, M.F.; Maurer, T.F.; Hahn, R.Z.; Perassolo, M.S.; Antunes, M.V.; Linden, R. Simultaneous Determination of Cocaine and Metabolites in Human Plasma Using Solid Phase Micro-Extraction Fiber Tips C18 and UPLC - MS / MS. J. Anal. Toxicol. 2019. [CrossRef]

134. Rasmussen, N. Amphetamine-Type Stimulants: The Early History of Their Medical and Non-Medical Uses, 1st ed.; Elsevier: Amsterdam, The Netherlands, 2015. [CrossRef]

135. Kalant, H. The pharmacology and toxicology of "ecstasy" (MDMA) and related drugs. Cmaj 2001, 165, 917-928. [PubMed]

136. Song, A.; Yang, J. Efficient determination of amphetamine and methylamphetamine in human urine using electro-enhanced singledrop microextraction with in-drop derivatization and gas chromatography. Anal. Chim. Acta 2019, 1045, 162-168. [CrossRef] [PubMed]

137. Taghvimi, A.; Tabrizi, A.B.; Dastmalchi, S.; Javadzadeh, Y. Metal organic framework based carbon porous as an efficient dispersive solid phase extraction adsorbent for analysis of methamphetamine from urine matrix. J. Chromatogr. B Anal. Technol. Biomed. Life Sci. 2019, 1109, 149-154. [CrossRef]

138. Maddadi, S.; Qomi, M.; Rajabi, M. Extraction, preconcentration, and determination of methylphenidate in urine sample using solvent bar microextraction in combination with HPLC-UV: Optimization by experimental design. J. Liq. Chromatogr. Relat. Technol. 2017, 40, 806-812. [CrossRef]

139. Abbasian, M.; Balali-Mood, M.; Salar Amoli, H.; Masoumi, A. A new solid-phase microextraction fiber for separation and determination of methamphetamines in human urine using sol-gel technique. J. Sol-Gel Sci. Technol. 2017, 81, 247-260. [CrossRef]

140. Rajabi, M.; Ghassab, N.; Hemmati, M.; Asghari, A. Emulsification microextraction of amphetamine and methamphetamine in complex matrices using an up-to-date generation of eco-friendly and relatively hydrophobic deep eutectic solvent. J. Chromatogr. A 2018, 1576, 1-9. [CrossRef]

141. Song, A.; Wang, J.; Lu, G.; Jia, Z.; Yang, J.; Shi, E. Oxidized multiwalled carbon nanotubes coated fibers for headspace solid-phase microextraction of amphetamine-type stimulants in human urine. Forensic Sci. Int. 2018, 290, 49-55. [CrossRef]

142. Shahvandi, S.K.; Banitaba, M.H.; Ahmar, H. Development of a new pH assisted homogeneous liquid-liquid microextraction by a solvent with switchable hydrophilicity: Application for GC-MS determination of methamphetamine. Talanta 2018, 184, 103-108. [CrossRef] [PubMed]

143. Mercieca, G.; Odoardi, S.; Cassar, M.; Strano Rossi, S. Rapid and simple procedure for the determination of cathinones, amphetamine-like stimulants and other new psychoactive substances in blood and urine by GC-MS. J. Pharm. Biomed. Anal. 2018, 149, 494-501. [CrossRef] [PubMed]

144. El-Beqqali, A.; Andersson, L.I.; Jeppsson, A.D.; Abdel-Rehim, M. Molecularly imprinted polymer-sol-gel tablet toward microsolid phase extraction: II. Determination of amphetamine in human urine samples by liquid chromatography-tandem mass spectrometry. J. Chromatogr. B Anal. Technol. Biomed. Life Sci. 2017, 1063, 130-135. [CrossRef] [PubMed]

145. Lin, Z.; Li, J.; Zhang, X.; Qiu, M.; Huang, Z.; Rao, Y. Ultrasound-assisted dispersive liquid-liquid microextraction for the determination of seven recreational drugs in human whole blood using gas chromatography-mass spectrometry. J. Chromatogr. $B$ Anal. Technol. Biomed. Life Sci. 2017, 1046, 177-184. [CrossRef]

146. de Souza Eller, S.C.W.; de Oliveira, F.; Yonamine, M. Measurement uncertainty for the determination of amphetamines in urine by liquid-phase microextraction and gas chromatography-mass spectrometry. Forensic Sci. Int. 2016, 265, 81-88. [CrossRef] [PubMed]

147. Wang, R.; Qi, X.; Zhao, L.; Liu, S.; Gao, S.; Ma, X.; Deng, Y. Ionic-liquid-based dispersive liquid-liquid microextraction coupled with high-performance liquid chromatography for the forensic determination of methamphetamine in human urine. J. Sep. Sci. 2016, 39, 2444-2450. [CrossRef]

148. Bagheri, H.; Zavareh, A.F.; Koruni, M.H. Graphene oxide assisted electromembrane extraction with gas chromatography for the determination of methamphetamine as a model analyte in hair and urine samples. J. Sep. Sci. 2016, 39, 1182-1188. [CrossRef]

149. Argente-García, A.; Moliner-Martínez, Y.; López-García, E.; Campíns-Falcó, P.; Herráez-Hernández, R. Application of Carbon Nanotubes Modified Coatings for the Determination of Amphetamines by In-Tube Solid-Phase Microextraction and Capillary Liquid Chromatography. Separations 2016, 3, 7. [CrossRef]

150. Cunha, R.L.; Lopes, W.A.; Pereira, P.A.P. Determination of free (unconjugated) amphetamine-type stimulants in urine samples by dispersive liquid-liquid microextraction and gas chromatography coupled to mass spectrometry (DLLME-GC-MS). Microchem. J. 2016, 125, 230-235. [CrossRef]

151. Akramipour, R.; Fattahi, N.; Pirsaheb, M.; Gheini, S. Combination of counter current salting-out homogenous liquid-liquid extraction and dispersive liquid-liquid microextraction as a novel microextraction of drugs in urine samples. J. Chromatogr. $B$ Anal. Technol. Biomed. Life Sci. 2016, 1012-1013, 162-168. [CrossRef]

152. Li, Z.; Zhang, S.; Cai, Y.; Wu, Q.; Chen, H. Hollow fiber-based solid-liquid phase microextraction combined with theta capillary electrospray ionization mass spectrometry for sensitive and accurate analysis of methamphetamine. Anal. Methods 2016, 8, 7800-7807. [CrossRef]

153. Kim, J.; Choi, K.; Chung, D.S. In-line coupling of single-drop microextraction with capillary electrophoresis-mass spectrometry. Anal. Bioanal. Chem. 2015, 407, 8745-8752. [CrossRef] [PubMed]

154. Zeng, J.; Chen, J.; Li, M.; Subhan, F.; Chong, F.; Wen, C.; Yu, J.; Cui, B.; Chen, X. Determination of amphetamines in biological samples using electro enhanced solid-phase microextraction-gas chromatography. J. Chromatogr. B Anal. Technol. Biomed. Life Sci. 2015, 1000, 169-175. [CrossRef] [PubMed] 
155. Rezazadeh, M.; Yamini, Y.; Seidi, S. Application of a new nanocarbonaceous sorbent in electromembrane surrounded solid phase microextraction for analysis of amphetamine and methamphetamine in human urine and whole blood. J. Chromatogr. A 2015, 1396, 1-6. [CrossRef] [PubMed]

156. Chen, X. Analysis of Methamphetamine in Human Urine Using Ionic Liquid Dispersive Liquid-Phase Microextraction Combined with HPLC. Chromatographia 2015, 78, 515-520. [CrossRef]

157. Zhang, S.; Cui, Y.; Sun, J.; Xi, Y.; Zhang, C.; Tang, J. Sensitive magnetic solid-phase microextraction based on oxide multi-walled carbon-nanotubes for the determination of methylamphetamine and ketamine in human urine and blood. Anal. Methods 2015, 7, 4209-4215. [CrossRef]

158. Narimani, O.; Dalali, N.; Rostamizadeh, K. Functionalized carbon nanotube/ionic liquid-coated wire as a new fiber assembly for determination of methamphetamine and ephedrine by gas chromatography-mass spectrometry. Anal. Methods 2014, 6, 8645-8653. [CrossRef]

159. Schuh, R.S.; Ferranti, P.; Ortiz, R.S.; Souza, D.Z.; Pechansky, F.; Froehlich, P.E.; Limberger, R.P. Simultaneous Analysis of Amphetamine-type Stimulants in Plasma by Solid-phase Microextraction and Gas Chromatography-Mass Spectrometry. J. Anal. Toxicol. 2014, 432-437.

160. Junkuy, A.; Pengwong, M.; Aramrattana, A.; Celentano, D. Validation and application of hair analysis for the detection of methamphetamine in young Thai adults. Asian Biomed. 2014, 8, 463-473. [CrossRef]

161. Ahmadi-Jouibari, T.; Fattahi, N.; Shamsipur, M. Rapid extraction and determination of amphetamines in human urine samples using dispersive liquid-liquid microextraction and solidification of floating organic drop followed by high performance liquid chromatography. J. Pharm. Biomed. Anal. 2014, 94, 145-151. [CrossRef]

162. Yin, T.; Basheer, C.; Jin, M.; Ang, Y.; Kee, H. Electroenhanced solid-phase microextraction of methamphetamine with commercial fibers. J. Chromatogr. A 2013, 1297, 12-16. [CrossRef]

163. Racamonde, I.; Rodil, R.; Quintana, J.B.; Cela, R. In-sample derivatization-solid-phase microextraction of amphetamines and ecstasy related stimulants from water and urine. Anal. Chim. Acta 2013, 770, 75-84. [CrossRef] [PubMed]

164. Airado-rodríguez, D.; Cruces-blanco, C.; García-campa, A.M. Dispersive liquid - liquid microextraction prior to field-amplified sample injection for the sensitive analysis of 3, 4-methylenedioxymethamphetamine, phencyclidine and lysergic acid diethylamide by capillary electrophoresis in human urine. J. Chromatogr. A 2012, 1267, 189-197. [CrossRef] [PubMed]

165. Djozan, D.; Farajzadeh, M.A. Determination of methamphetamine, amphetamine and ecstasy by inside-needle adsorption trap based on molecularly imprinted polymer followed by GC-FID determination. Microchim. Acta 2012, 209-217. [CrossRef]

166. Rezaee, M.; Mashayekhi, H.A.; Garmaroudi, S.S. Simultaneous determination of amphetamine and related compounds in human urine using ultrasound-assisted emulsification microextraction and gas chromatography. Anal. Methods 2012, 4, 3212-3218. [CrossRef]

167. Pantaleão, N.; Aparecida, B.; Bismara, P.; Yonamine, M. Hollow-fiber liquid-phase microextraction of amphetamine-type stimulants in human hair samples. J. Chromatogr. A 2012, 1254, 1-7. [CrossRef]

168. Mashayekhi, H.A.; Rezaee, M. Determination of Ecstasy Components in Human Urine by Gas Chromatography using a Dispersive Liquid-Liquid Microextraction Procedure. J. Braz. Chem. Soc. 2012, 23, 1698-1703. [CrossRef]

169. Djozan, D.; Ali, M.; Mohammad, S.; Baheri, T. Molecularly imprinted-solid phase extraction combined with simultaneous derivatization and dispersive liquid-Liquid microextraction for selective extraction and preconcentration of methamphetamine and ecstasy from urine samples followed by gas chromatog. J. Chromatogr. A 2012, 1248, 24-31. [CrossRef]

170. Saber Tehrani, M.; Givianrad, M.H.; Mahoor, N. Surfactant-assisted dispersive liquid-liquid microextraction followed by highperformance liquid chromatography for determination of amphetamine and methamphetamine in urine samples. Anal. Methods 2012, 4, 1357-1364. [CrossRef]

171. Elén, R.; Jamt, G.; Gjelstad, A.; Erik, L.; Eibak, E.; Leere, E.; Solberg, A.; Einar, K.; Pedersen-bjergaard, S. Electromembrane extraction of stimulating drugs from undiluted whole blood. J. Chromatogr. A 2012, 1232, 27-36. [CrossRef]

172. Seidi, S.; Yamini, Y.; Baheri, T.; Feizbakhsh, R. Electrokinetic extraction on artificial liquid membranes of amphetamine-type stimulants from urine samples followed by high performance liquid chromatography analysis. J. Chromatogr. A 2011, 1218, 3958-3965. [CrossRef] [PubMed]

173. Zeng, J.; Zou, J.; Song, X.; Chen, J.; Ji, J.; Wang, B.; Wang, Y.; Ha, J.; Chen, X. A new strategy for basic drug extraction in aqueous medium using electrochemically enhanced solid-phase microextraction. J. Chromatogr. A 2011, 1218, 191-196. [CrossRef] [PubMed]

174. Xiong, J.; Chen, J.; He, M.; Hu, B. Simultaneous quantification of amphetamines, caffeine and ketamine in urine by hollow fiber liquid phase microextraction combined with gas chromatography-flame ionization detector. Talanta 2010, 82, 969-975. [CrossRef] [PubMed]

175. Es'haghi, Z.; Mohtaji, M.; Hasanzade-Meidani, M.; Masrournia, M. The measurement of ecstasy in human hair by triple phase directly suspended droplet microextraction prior to HPLC-DAD analysis. J. Chromatogr. B Anal. Technol. Biomed. Life Sci. 2010, 878, 903-908. [CrossRef] [PubMed]

176. He, Y.; Pohl, J.; Engel, R.; Rothman, L.; Thomas, M. Preparation of ionic liquid based solid-phase microextraction fiber and its application to forensic determination of methamphetamine and amphetamine in human urine. J. Chromatogr. A 2009, 1216, 4824-4830. [CrossRef] 
177. Wise, J.; Danielson, T.; Mozayani, A.; Li, R. Analysis of amphetamine, methamphetamine, methylenedioxyamphetamine and methylenedioxymethamphetamine in whole blood using in-matrix ethyl chloroformate derivatization and automated headspace solid-phase microextraction followed by GC-MS. Forensic Toxicol. 2008, 26, 66-70. [CrossRef]

178. Namera, A.; Nakamoto, A.; Nishida, M.; Saito, T.; Kishiyama, I.; Miyazaki, S.; Yahata, M.; Yashiki, M.; Nagao, M. Extraction of amphetamines and methylenedioxyamphetamines from urine using a monolithic silica disk-packed spin column and highperformance liquid chromatography-diode array detection. J. Chromatogr. A 2008, 1208, 71-75. [CrossRef]

179. Chiang, J.S.; Huang, S. Da Simultaneous derivatization and extraction of amphetamine and methylenedioxyamphetamine in urine with headspace liquid-phase microextraction followed by gas chromatography-mass spectrometry. J. Chromatogr. A 2008, 1185, 19-22. [CrossRef]

180. Alizadeh, N.; Mohammadi, A.; Tabrizchi, M. Rapid screening of methamphetamines in human serum by headspace solid-phase microextraction using a dodecylsulfate-doped polypyrrole film coupled to ion mobility spectrometry. J. Chromatogr. A 2008, 1183, 21-28. [CrossRef]

181. He, Y.; Vargas, A.; Kang, Y.J. Headspace liquid-phase microextraction of methamphetamine and amphetamine in urine by an aqueous drop. Anal. Chim. Acta 2007, 589, 225-230. [CrossRef] [PubMed]

182. He, Y.; Kang, Y.J. Single drop liquid-liquid-liquid microextraction of methamphetamine and amphetamine in urine. J. Chromatogr. A 2006, 1133, 35-40. [CrossRef] [PubMed]

183. Nishida, M.; Yashiki, M.; Namera, A.; Kimura, K. Single hair analysis of methamphetamine and amphetamine by solid phase microextraction coupled with in matrix derivatization. J. Chromatogr. B Anal. Technol. Biomed. Life Sci. 2006, 842, 106-110. [CrossRef] [PubMed]

184. Zhou, J.; Zeng, Z. Novel fiber coated with $\beta$-cyclodextrin derivatives used for headspace solid-phase microextraction of ephedrine and methamphetamine in human urine. Anal. Chim. Acta 2006, 556, 400-406. [CrossRef]

185. Chia, K.J.; Huang, S. Da Simultaneous derivatization and extraction of amphetamine-like drugs in urine with headspace solid-phase microextraction followed by gas chromatography-mass spectrometry. Anal. Chim. Acta 2005, 539, 49-54. [CrossRef]

186. Chou, C.C.; Lee, M.R. Solid phase microextraction with liquid chromatography-electrospray ionization-tandem mass spectrometry for analysis of amphetamine and methamphetamine in serum. Anal. Chim. Acta 2005, 538, 49-56. [CrossRef]

187. Lokhnauth, J.K.; Snow, N.H. Solid phase micro-extraction coupled with ion mobility spectrometry for the analysis of ephedrine in urine. J. Sep. Sci. 2005, 28, 612-618. [CrossRef]

188. Cháfer-Pericás, C.; Campíns-Falcó, P.; Herráez-Hernández, R. Application of solid-phase microextraction combined with derivatization to the determination of amphetamines by liquid chromatography. Anal. Biochem. 2004, 333, 328-335. [CrossRef]

189. Raikos, N.; Christopoulou, K.; Theodoridis, G.; Tsoukali, H.; Psaroulis, D. Determination of amphetamines in human urine by headspace solid-phase microextraction and gas chromatography. J. Chromatogr. B Anal. Technol. Biomed. Life Sci. 2003, 789, 59-63. [CrossRef]

190. Yonamine, M.; Tawil, N.; De Moraes Moreau, R.L.; Alves Silva, O. Solid-phase micro-extraction-gas chromatography-mass spectrometry and headspace-gas chromatography of tetrahydrocannabinol, amphetamine, methamphetamine, cocaine and ethanol in saliva samples. J. Chromatogr. B Anal. Technol. Biomed. Life Sci. 2003, 789, 73-78. [CrossRef]

191. McCooeye, M.A.; Mester, Z.; Ells, B.; Barnett, D.A.; Purves, R.W.; Guevremont, R. Quantitation of amphetamine, methamphetamine, and their methylenedioxy derivatives in urine by solid-phase microextraction coupled with electrospray ionizationhigh-field asymmetric waveform ion mobility spectrometry-mass spectrometry. Anal. Chem. 2002, 74, 3071-3075. [CrossRef]

192. Musshoff, F.; Lachenmeier, D.W.; Kroener, L.; Madea, B. Automated headspace solid-phase dynamic extraction for the determination of amphetamines and synthetic designer drugs in hair samples. J. Chromatogr. A 2002, 958, 231-238. [CrossRef]

193. Goto, Y.; Takeda, S.; Araki, T.; Fuchigami, T. Method of simultaneous stir bar sorptive extraction of phenethylamines and THC metabolite from urine. J. Toxicol. Sci. 2011, 36, 523-529. [CrossRef] [PubMed]

194. Lan, L.; Hu, B.; Yu, C. PH-resistant titania hybrid organic-inorganic coating for stir bar sorptive extraction of drugs of abuse in urine samples followed by high performance liquid chromatography-ultraviolet visible detection. J. Chromatogr. A 2010, 1217, 7003-7009. [CrossRef] [PubMed]

195. Casari, C.; Andrews, A.R.J. Application of solvent microextraction to the analysis of amphetamines and phencyclidine in urine. Forensic Sci. Int. 2001, 120, 165-171. [CrossRef]

196. Brown, S.D.; Rhodes, D.J.; Pritchard, B.J. A validated SPME-GC-MS method for simultaneous quantification of club drugs in human urine. Forensic Sci. Int. 2007, 171, 142-150. [CrossRef] [PubMed]

197. Alsenedi, K.A.; Morrison, C. Determination of amphetamine-type stimulants (ATSs) and synthetic cathinones in urine using solid phase micro-extraction fibre tips and gas chromatography-mass spectrometry. Anal. Methods 2018, 10, 1431-1440. [CrossRef]

198. Jahed, S.; Arezou, O.; Siavoush, T.; Yousef, D. Silica-Functionalized Nano-Graphene Oxide Composite as Potent-Dispersive Solid-Phase Extraction Adsorbent of Methylphenidate from Urine Samples. Arab. J. Sci. Eng. 2020, 45, 4697-4704. [CrossRef]

199. Bombana, H.S.; Filonzi, M.; Muñoz, D.R.; Leyton, V. Hollow-fibre liquid-phase microextraction and gas chromatography-mass spectrometric determination of amphetamines in whole blood. J. Chromatogr. B 2020, 1139, 121973. [CrossRef]

200. Jabbari, N.R.; Taghvimi, A.; Dastmalchi, S.; Javadzadeh, Y. Dispersive solid-phase extraction adsorbent of methamphetamine using in-situ synthesized carbon-based conductive polypyrrole nanocomposite: Focus on clinical applications in human urine. $J$. Sep. Sci. 2019, 43, 606-613. [CrossRef] 
201. Andersson, M.; Scheidweiler, K.B.; Sempio, C.; Barnes, A.J.; Huestis, M.A. Simultaneous quantification of 11 cannabinoids and metabolites in human urine by liquid chromatography tandem mass spectrometry using WAX-S tips. Anal. Bioanal. Chem. 2016, 408, 6461-6471. [CrossRef] [PubMed]

202. Sánchez-González, J.; Salgueiro-Fernández, R.; Cabarcos, P.; Bermejo, A.M.; Bermejo-Barrera, P.; Moreda-Piñeiro, A. Cannabinoids assessment in plasma and urine by high performance liquid chromatography-tandem mass spectrometry after molecularly imprinted polymer microsolid-phase extraction. Anal. Bioanal. Chem. 2017, 409, 1207-1220. [CrossRef]

203. de Oliveira Silveira, G.; Loddi, S.; de Oliveira, C.D.R.; Zucoloto, A.D.; Fruchtengarten, L.V.G.; Yonamine, M. Headspace solidphase microextraction and gas chromatography-mass spectrometry for determination of cannabinoids in human breast milk. Forensic Toxicol. 2017, 35, 125-132. [CrossRef]

204. Emídio, E.S.; de Menezes Prata, V.; de Santana, F.J.M.; Dórea, H.S. Hollow fiber-based liquid phase microextraction with factorial design optimization and gas chromatography-tandem mass spectrometry for determination of cannabinoids in human hair. $J$. Chromatogr. B Anal. Technol. Biomed. Life Sci. 2010, 878, 2175-2183. [CrossRef] [PubMed]

205. Rosado, T.; Fernandes, L.; Barroso, M.; Gallardo, E. Sensitive determination of THC and main metabolites in human plasma by means of microextraction in packed sorbent and gas chromatography-tandem mass spectrometry. J. Chromatogr. B Anal. Technol. Biomed. Life Sci. 2017, 1043, 63-73. [CrossRef]

206. De Souza Eller, S.C.W.; Flaiban, L.G.; Paranhos, B.A.P.B.; Da Costa, J.L.; Lourenço, F.R.; Yonamine, M. Analysis of 11-nor-9carboxy- $\Delta$ 9-tetrahydrocannabinol in urine samples by hollow fiber-liquid phase microextraction and gas chromatography-mass spectrometry in consideration of measurement uncertainty. Forensic Toxicol. 2014, 32, 282-291. [CrossRef]

207. Anzillotti, L.; Castrignanò, E.; Rossi, S.S.; Chiarotti, M. Cannabinoids determination in oral fluid by SPME-GC/MS and UHPLCMS/MS and its application on suspected drivers. Sci. Justice 2014, 54, 421-426. [CrossRef]

208. Scheidweiler, K.B.; Newmeyer, M.N.; Barnes, A.J.; Huestis, M.A. Quantification of cannabinoids and their free and glucuronide metabolites in whole blood by disposable pipette extraction and liquid chromatography-tandem mass spectrometry. J. Chromatogr. A 2016, 1453, 34-42. [CrossRef]

209. Montesano, C.; Sergi, M.; Odoardi, S.; Simeoni, M.C.; Compagnone, D.; Curini, R. A $\mu$-SPE procedure for the determination of cannabinoids and their metabolites in urine by LC-MS/MS. J. Pharm. Biomed. Anal. 2014, 91, 169-175. [CrossRef]

210. Sergi, M.; Montesano, C.; Odoardi, S.; Mainero Rocca, L.; Fabrizi, G.; Compagnone, D.; Curini, R. Micro extraction by packed sorbent coupled to liquid chromatography tandem mass spectrometry for the rapid and sensitive determination of cannabinoids in oral fluids. J. Chromatogr. A 2013, 1301, 139-146. [CrossRef]

211. Emídio, E.S.; de Menezes Prata, V.; Dórea, H.S. Validation of an analytical method for analysis of cannabinoids in hair by headspace solid-phase microextraction and gas chromatography-ion trap tandem mass spectrometry. Anal. Chim. Acta 2010, 670, 63-71. [CrossRef] [PubMed]

212. Goto, Y.; Araki, T.; Fuchigami, T.; Arizono, K. Analysis of 11-nor-9-carboxy- $\Delta$ 9-tetrahydrocannabinol in urine by LC-MS-MS after stir-bar sorptive extraction and liquid desorption. Forensic Toxicol. 2010, 28, 38-42. [CrossRef]

213. Luo, D.; Chen, F.; Xiao, K.; Feng, Y.Q. Rapid determination of $\Delta 9$-Tetrahydrocannabinol in saliva by polymer monolith microextraction combined with gas chromatography-mass spectrometry. Talanta 2009, 77, 1701-1706. [CrossRef] [PubMed]

214. Schroeder, J.L.; Marinetti, L.J.; Smith, R.K.; Brewer, W.E.; Clelland, B.L.; Morgan, S.L. The analysis of delta9-tetrahydrocannabinol and metabolite in whole blood and 11-nor-delta9-tetrahydrocannabinol-9-carboxylic acid in urine using disposable pipette extraction with confirmation and quantification by gas chromatography-mass spectrometry. J. Anal. Toxicol. 2008, 32, 659-666. [CrossRef] [PubMed]

215. Nadulski, T.; Pragst, F. Simple and sensitive determination of??9-tetrahydrocannabinol, cannabidiol and cannabinol in hair by combined silylation, headspace solid phase microextraction and gas chromatography-mass spectrometry. J. Chromatogr. B Anal. Technol. Biomed. Life Sci. 2007, 846, 78-85. [CrossRef] [PubMed]

216. Rodrigues de Oliveira, C.D.; Yonamine, M.; de Moraes Moreau, R.L. Headspace solid-phase microextraction of cannabinoids in human head hair samples. J. Sep. Sci. 2007, 30, 128-134. [CrossRef]

217. Franklin, T.; Perry, L.; Shih, W.C.; Yu, J. Detection of phytocannabinoids from buccal swabs by headspace solid phase microextraction-gas chromatography/mass spectrometry. Anal. Methods 2018, 10, 942-946. [CrossRef]

218. Souza, I.D.; Hantao, L.W.; Queiroz, M.E.C. Polymeric ionic liquid open tubular capillary column for on-line in-tube SPME coupled with UHPLC-MS/MS to determine endocannabinoids in plasma samples. Anal. Chim. Acta 2019, 1045, 108-116. [CrossRef]

219. Anzillotti, L.; Marezza, F.; Calò, L.; Andreoli, R.; Agazzi, S.; Bianchi, F.; Careri, M.; Cecchi, R. Determination of synthetic and natural cannabinoids in oral fluid by solid-phase microextraction coupled to gas chromatography/mass spectrometry: A pilot study. Talanta 2019, 201, 335-341. [CrossRef]

220. Ncube, S.; Poliwoda, A.; Tutu, H.; Wieczorek, P.; Chimuka, L. Multivariate optimization of the hollow fibre liquid phase microextraction of muscimol in human urine samples. J. Chromatogr. B Anal. Technol. Biomed. Life Sci. 2016, 1033-1034, 372-381. [CrossRef]

221. Dinis-Oliveira, R.J. Metabolism and metabolomics of ketamine: A toxicological approach. Forensic Sci. Res. 2017, 2, 2-10. [CrossRef]

222. Ishii, A.; Seno, H.; Kumazawa, T.; Watanabe, K.; Hattori, H.; Suzuki, O. Simple Extraction of Phencyclidine from Human Body Fluids by Headspace Solid-Phase Microextraction (SPME). Chromatographia 1996, 43, 331-333. [CrossRef] 
223. Ahmad, S.M.; Oliveira, M.N.; Neng, N.R.; Nogueira, J.M.F. A fast and validated high throughput bar adsorptive microextraction (HT-BA $\mu \mathrm{E})$ method for the determination of ketamine and norketamine in urine samples. Molecules 2020, 25, 1438. [CrossRef] [PubMed]

224. Fakhari, A.R.; Koruni, M.H.; Ahmar, H.; Shahsavani, A.; Movahed, S.K. Electrochemical Determination of Dextromethorphan on Reduced Graphene Oxide Modified Screen-Printed Electrode after Electromembrane Extraction. Electroanalysis 2014, 26, 521-529. [CrossRef]

225. Mirmahdieh, S.; Khayamian, T.; Saraji, M. Analysis of dextromethorphan and pseudoephedrine in human plasma and urine samples using hollow fiber-based liquid-liquid-liquid microextraction and corona discharge ion mobility spectrometry. Microchim. Acta 2012, 176, 471-478. [CrossRef]

226. Barnes, B.B.; Snow, N.H. Analysis of Salvinorin A in plants, water, and urine using solid-phase microextraction-comprehensive two-dimensional gas chromatography-time of flight mass spectrometry. J. Chromatogr. A 2012, 1226, 110-115. [CrossRef] [PubMed]

227. Liu, X.; Fu, R.; Li, M.; Guo, L.P.; Yang, L. Ionic liquid-based dispersive liquid-liquid microextraction coupled with capillary electrophoresis to determine drugs of abuse in urine. Fenxi Huaxue/ Chinese J. Anal. Chem. 2013, 41, 1919-1922. [CrossRef]

228. Sporkert, F.; Pragst, F. Use of headspace solid-phase microextraction (HS-SPME) in hair analysis for organic compounds. Forensic Sci. Int. 2000, 107, 129-148. [CrossRef]

229. Moreno, I.; Barroso, M.; Martinho, A.; Cruz, A.; Gallardo, E. Determination of ketamine and its major metabolite, norketamine, in urine and plasma samples using microextraction by packed sorbent and gas chromatography-tandem mass spectrometry. $J$. Chromatogr. B Anal. Technol. Biomed. Life Sci. 2015, 1004, 67-78. [CrossRef]

230. Hu, B.; Zheng, B.; Rickert, D.; Gómez-Ríos, G.A.; Bojko, B.; Pawliszyn, J.; Yao, Z.P. Direct coupling of solid phase microextraction with electrospray ionization mass spectrometry: A Case study for detection of ketamine in urine. Anal. Chim. Acta 2019, 1075, 112-119. [CrossRef]

231. Bagheri, H.; Es-haghi, A.; Rouini, M.R. Sol-gel-based solid-phase microextraction and gas chromatography-mass spectrometry determination of dextromethorphan and dextrorphan in human plasma. J. Chromatogr. B Anal. Technol. Biomed. Life Sci. 2005, 818, 147-157. [CrossRef]

232. de Bairros, A.V.; Lanaro, R.; de Almeida, R.M.; Yonamine, M. Determination of ketamine, norketamine and dehydronorketamine in urine by hollow-fiber liquid-phase microextraction using an essential oil as supported liquid membrane. Forensic Sci. Int. 2014, 243, 47-54. [CrossRef]

233. Bianchi, F.; Agazzi, S.; Riboni, N.; Erdal, N.; Hakkarainen, M.; Ilag, L.L.; Anzillotti, L.; Andreoli, R.; Marezza, F.; Moroni, F.; et al. Novel sample-substrates for the determination of new psychoactive substances in oral fluid by desorption electrospray ionization-high resolution mass spectrometry. Talanta 2019, 202, 136-144. [CrossRef]

234. Odoardi, S.; Fisichella, M.; Romolo, F.S.; Strano-Rossi, S. High-throughput screening for new psychoactive substances (NPS) in whole blood by DLLME extraction and UHPLC-MS/MS analysis. J. Chromatogr. B Anal. Technol. Biomed. Life Sci. 2015, 1000, 57-68. [CrossRef] [PubMed]

235. Maurer, H.H.; Brandt, S.D. New Psychoactive Substances; Pharmacology, Clinical, Forensic and Analytical Toxicology; Springer: New York, NY, USA, 2018. [CrossRef]

236. European Monitoring Centre for Drugs and Drug Addiction. European Drug Report 2019: Trends and Developments; Publications Office of the European Union: Luxembourg, 2019.

237. Neng, N.R.; Ahmad, S.M.; Gaspar, H.; Nogueira, J.M.F. Determination of mitragynine in urine matrices by bar adsorptive microextraction and HPLC analysis. Talanta 2015, 144. [CrossRef]

238. Montesano, C.; Vannutelli, G.; Piccirilli, V.; Sergi, M.; Compagnone, D.; Curini, R. Application of a rapid $\mu$-SPE clean-up for multiclass quantitative analysis of sixteen new psychoactive substances in whole blood by LC-MS/MS. Talanta 2017, 167, 260-267. [CrossRef] [PubMed]

239. Moreno, I.E.D.; da Fonseca, B.M.; Barroso, M.; Costa, S.; Queiroz, J.A.; Gallardo, E. Determination of piperazine-type stimulants in human urine by means of microextraction in packed sorbent and high performance liquid chromatography-diode array detection. J. Pharm. Biomed. Anal. 2012, 61, 93-99. [CrossRef] [PubMed]

240. Moreno, I.E.D.; da Fonseca, B.M.; Magalhães, A.R.; Geraldes, V.S.; Queiroz, J.A.; Barroso, M.; Costa, S.; Gallardo, E. Rapid determination of piperazine-type stimulants in human urine by microextraction in packed sorbent after method optimization using a multivariate approach. J. Chromatogr. A 2012, 1222, 116-120. [CrossRef] [PubMed]

241. Peiró, M.D.L.N.; Armenta, S.; Garrigues, S.; De La Guardia, M. Determination of 3,4-methylenedioxypyrovalerone (MDPV) in oral and nasal fluids by ion mobility spectrometry. Anal. Bioanal. Chem. 2016, 408, 3265-3273. [CrossRef]

242. Rocchi, R.; Simeoni, M.C.; Montesano, C.; Vannutelli, G.; Curini, R.; Sergi, M.; Compagnone, D. Analysis of new psychoactive substances in oral fluids by means of microextraction by packed sorbent followed by ultra-high-performance liquid chromatography-tandem mass spectrometry. Drug Test. Anal. 2018, 10, 865-873. [CrossRef]

243. Sánchez-González, J.; Odoardi, S.; Bermejo, A.M.; Bermejo-Barrera, P.; Romolo, F.S.; Moreda-Piñeiro, A.; Strano-Rossi, S. HPLC-MS/MS combined with membrane-protected molecularly imprinted polymer micro-solid-phase extraction for synthetic cathinones monitoring in urine. Drug Test. Anal. 2019, 11, 33-44. [CrossRef] [PubMed]

244. Sorribes-Soriano, A.; Monedero, A.; Esteve-Turrillas, F.A.; Armenta, S. Determination of the new psychoactive substance dichloropane in saliva by microextraction by packed sorbent - Ion mobility spectrometry. J. Chromatogr. A 2019, 1603, 61-66. [CrossRef] [PubMed] 
245. Vårdal, L.; Askildsen, H.M.; Gjelstad, A.; Øiestad, E.L.; Edvardsen, H.M.E.; Pedersen-Bjergaard, S. Parallel artificial liquid membrane extraction of new psychoactive substances in plasma and whole blood. J. Chromatogr. B Anal. Technol. Biomed. Life Sci. 2017, 1048, 77-84. [CrossRef]

246. Mercieca, G.; Strano-rossi, S.; Odoardi, S.; Mestria, S.; Cassar, M. Application of ultrasound-assisted liquid-liquid microextraction coupled with gas chromatography and mass spectrometry for the rapid determination of synthetic cannabinoids and metabolites in biological samples. J. Sep. Sci. 2020, 43, 2858-2868. [CrossRef] [PubMed] 